\title{
State Differences in the Vocational Rehabilitation Experiences of Transition-Age Youth with Disabilities
}

\author{
Todd Honeycutt \\ Allison Thompkins \\ Maura Bardos \\ Steven Stern
}

October 2013

\section{MATHEMATICA \\ Policy Research}

Project \#: 40112.305 
This page has been left blank for double-sided copying. 


\title{
State Differences in the Vocational Rehabilitation Experiences of Transition-Age Youth with Disabilities
}

\author{
Todd Honeycutt* \\ Mathematica Policy Research \\ Allison Thompkins \\ Mathematica Policy Research \\ Maura Bardos \\ Mathematica Policy Research \\ Steven Stern \\ University of Virginia
}

October 2013

\author{
Mathematica Policy Research \\ P. O. Box 2393 \\ Princeton, NJ 08543 \\ http://www.disabilitypolicyresearch.org/DRC/
}

(609) 945-3397

This paper contains information which resulted from work performed pursuant to a grant from the U.S. Social Security Administration (SSA) funded as part of the Disability Research Consortium (cooperative agreement No. 1-DRC12000001-01-00). The opinions and conclusions expressed are solely those of the authors and do not represent the opinions or policy of Mathematica Policy Research, SSA, or any agency with the Federal Government. 
This page has been left blank for double-sided copying. 


\section{CONTENTS}

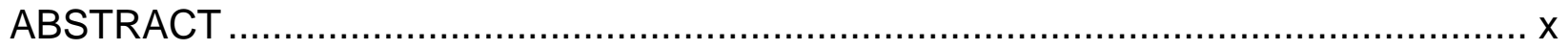

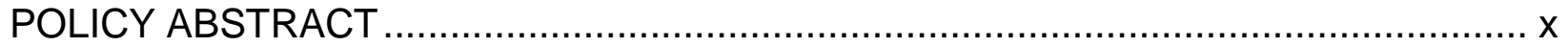

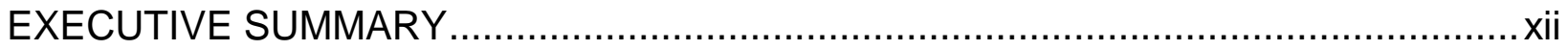

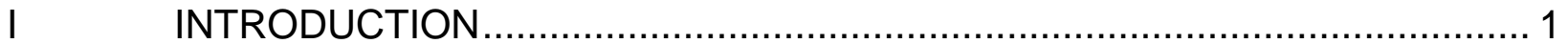

A. Poor Employment and Education Outcomes for Youth with Disabilities.............................................................. 1

B. VR Agencies Can Help Youth Overcome

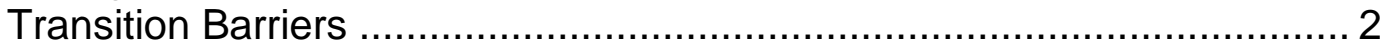

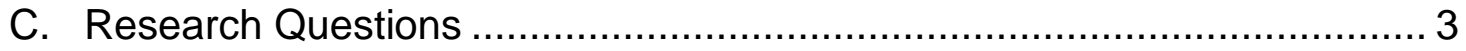

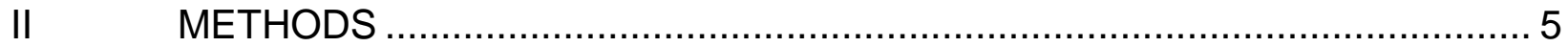

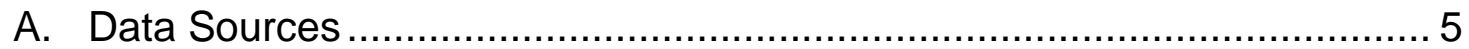

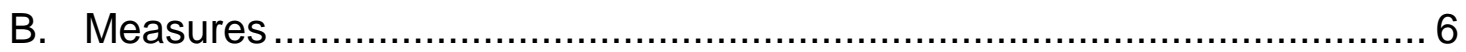

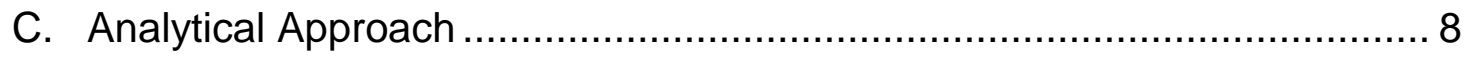

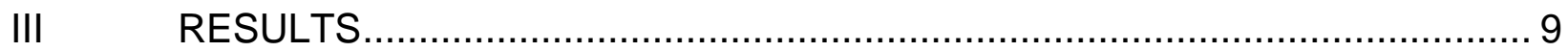

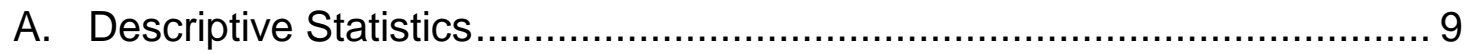

B. VR Agency Transition-Age Youth Ratios .......................................... 12

C. Agency and State Factors Influencing the

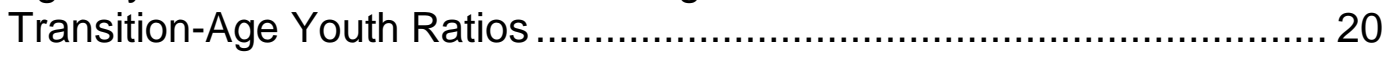

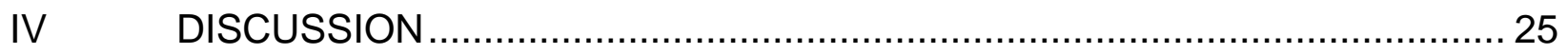

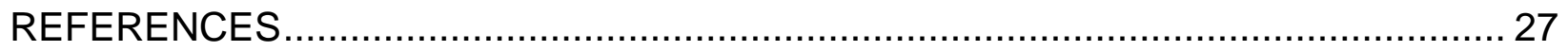

APPENDIX A AGENCY-AND STATE-LEVEL DATA FOR TABLES III.1, III.2 AND III.3 
This page has been left blank for double-sided copying. 


\section{TABLES}

III.1 Descriptive Statistics of the Individual Characteristics of VR Applicants Aged 16 to 24, 2004-2006.................................................... 10

III.2 Characteristics of States and State VR Agencies, 2004-2006.................... 11

III.3 Transition Staff and Order of Selection Characteristics of State VR Agencies, 2004-2006 ....................................................... 12

III.4 State VR Agency Transition Ratios and Comparative

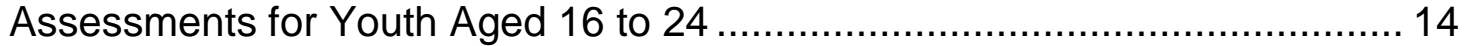

III.5 Correlations among State VR Agency Transition Ratios ............................. 20

III.6 Correlations of Agency and State Factors with Agency

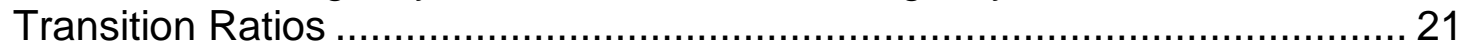

III.7 Ratio Means for Transition Counselor Level and OOS ................................ 23 
This page has been left blank for double-sided copying. 


\section{FIGURES}

III.1 Applicant Ratio (Ratio of VR Youth Applicants to the State

Population of Youth with Disabilities), by State

III.2 Service Ratio (Ratio of Youth Who Receive VR Services Among

Those Who Apply), by State.

III.3 Employment Ratio (Ratio of VR Youth with Positive Employment

Outcomes to Youth Served), by State.

III.4 Relative Employment Ratio (VR Youth with Employment Outcomes

to State-Level Employed Youth with Disabilities), by State

III.5 Proportion of Youth With Disabilities Who Closed from VR with

Employment, by State

III.6 Quartiles of the Proportion of Transition-Age Youth Who Received

VR Services and Closed with Employment Outcomes, by State 
This page has been left blank for double-sided copying. 


\begin{abstract}
State vocational rehabilitation (VR) agencies play a critical role in helping transition-age youth with disabilities attain their vocational goals. However, there is insufficient knowledge about best practices for agencies in serving transition-age youth. Because of the persistent poor employment outcomes of transition-age youth with disabilities, policymakers and the disability community consider it highly important to ensure successful work-related outcomes for this population. This report presents new state-level statistics on the outcomes for a cohort of youth who applied for VR services from 2004 through 2006, obtained by merging RSA-911 closure data across several years. States had wide variation in how their VR agencies served transition-age youth populations. Across states, the percentage of transition-age youth applying for VR services ranged from 4 to 14 percent, the percentage of applicants receiving VR services ranged from 31 to 82 percent, and the percentage of youth who received VR services and who closed with an employment outcome ranged from 40 to 70 percent. Several agency- and state-level factors, such as the unemployment rate and the amount of resources available to the VR agency, were correlated with the statistics presented. Although the wide variation in transition statistics suggests that policymakers could improve VR services for transition-age youth by developing specific standards and guidelines for VR agencies serving this population, this study points out several limitations and challenges in such an approach.
\end{abstract}

\title{
POLICY ABSTRACT
}

This study presents new state-level statistics on the outcomes for a cohort of transition-age youth who applied for VR services from 2004 through 2006 and shows that VR agencies had sizeable variation in all five transition statistics presented. Youth represent a substantial proportion-nearly one-third-of the population VR agencies serve. Their unique vocational and education needs are one reason why many agencies focus on this population-for example, by having dedicated counselors and vocational programs specifically for youth. If policymakers want to promote the services the transition-age population receives, they could develop specific standards and indicators for agencies regarding this population. RSA currently has standards and indicators for the general population that agencies serve. It also includes measures specific to youth as a special population in annual reports. Expanding this focus by setting standards for all agencies for how each should serve youth could have an effect on increasing the number of youth who receive services and, therefore, might obtain better employment outcomes. Such identification of goals and public monitoring of such efforts could lead to some agencies changing how they work with youth. The key question, though, is what the agency standards should be. If RSA develops standards for the transition-age population, those measures should account for state characteristics, acknowledge the different types of youth that agencies serve, and be based on cohorts of applicants. 
This page has been left blank for double-sided copying. 


\section{EXECUTIVE SUMMARY}

State vocational rehabilitation (VR) agencies play a critical role in helping transition-age youth with disabilities attain their vocational goals. However, there is insufficient knowledge about best practices for agencies in serving transition-age youth. Because of the persistent poor employment outcomes of transition-age youth with disabilities, ensuring successful work-related outcomes for this population is very important to policymakers and the disability community.

The study addressed three questions: (1) To what extent does each state's population of transition-age youth with disabilities apply for VR services? (2) Among those who apply, how likely is it that a transition-age youth will receive services? and (3) What proportion of youth who receive VR services have their cases closed with an employment outcome, and how does that compare with the employment rate for the state's entire population of transition-age youth with disabilities? We used data from the RSA-911 Case Service Report (which allowed us to develop application and closure cohort files for youth and young adults who applied for VR services in fiscal years 2004, 2005, and 2006), along with other publicly available data.

Our analysis provides statistics on each VR agency's involvement with transition-age youth, as reflected in four ratios: (1) applicant ratio (the number of VR youth applicants divided by the number of youth with disabilities), (2) service ratio (the number of youth who received VR services divided by the number of youth who applied), (3) employment ratio (the number of youth who exited VR with employment divided by the number of youth who received services), and (4) relative employment ratio (the employment ratio divided by the employment rate of all youth with disabilities). We also calculated a summary statistic by multiplying the first three ratios together. The ratios capture agency involvement at distinct stages in their work with transition-age youth and are comparable across agencies. The statistics presented here represent an initial examination of how agencies work with transition-age youth. Values that are high or low do not indicate better or worse performance, because many factors outside an agency's control can influence these statistics.

VR agencies had sizeable variation in their transition ratios:

- Applicant ratio. On average, each year from 2004 through 2006, 8 percent of U.S. youth with disabilities ages 16 to 24 applied for VR services. The ratio ranged from 4 percent in Alaska, Connecticut, and Washington to 14 percent in Iowa and North Dakota.

- Service ratio. Across the United States, 56 percent of transition-age youth who applied for VR services eventually received them. This ratio ranged from 31 percent in Tennessee and 36 percent in Missouri to 82 percent in Alabama.

- Employment ratio. Nationally, of transition-age youth with disabilities who applied from 2004 through 2006 and received services, 56 percent closed their cases and were employed at the time they closed from VR. The VR agency in Wyoming had the highest employment ratio (70 percent), closely followed by agencies in Colorado, Missouri, and Utah. On the low end, applicants to the VR agency in Louisiana achieved positive employment outcomes 40 percent of the time.

- Relative employment ratio. Transition-age youth served by VR agencies had employment rates at closure that were, on average, 86 percent of the employment rates observed for all youth with disabilities. Again, as with the other ratios, agencies had sizeable variation in the value of the relative employment ratio (from 45 to 116 percent). 
Across the United States, 2.3 percent of transition-age youth applied for and received VR services and were employed when they closed from services. The U.S. map in Figure ES-1 shows the quartile ranking of states; state agencies with the highest values are shaded dark gray, and state agencies with the lowest values are shaded white. Alabama had the highest value for this statistic; among its transition-age youth population with disabilities, nearly seven percent sought and received VR services and exited with an employment outcome. The agencies with the next highest value of this statistic included those in Delaware, West Virginia, North Dakota, Idaho, and Vermont. In contrast, the agencies in Louisiana, Connecticut, and Washington had the lowest values; no more than one percent of youth in those states applied for and received services and exited with a positive employment outcome.

\section{Figure ES-1. Quartiles of the Proportion of Transition-Age Youth Who Received VR Services and Closed with Employment Outcomes, by State}

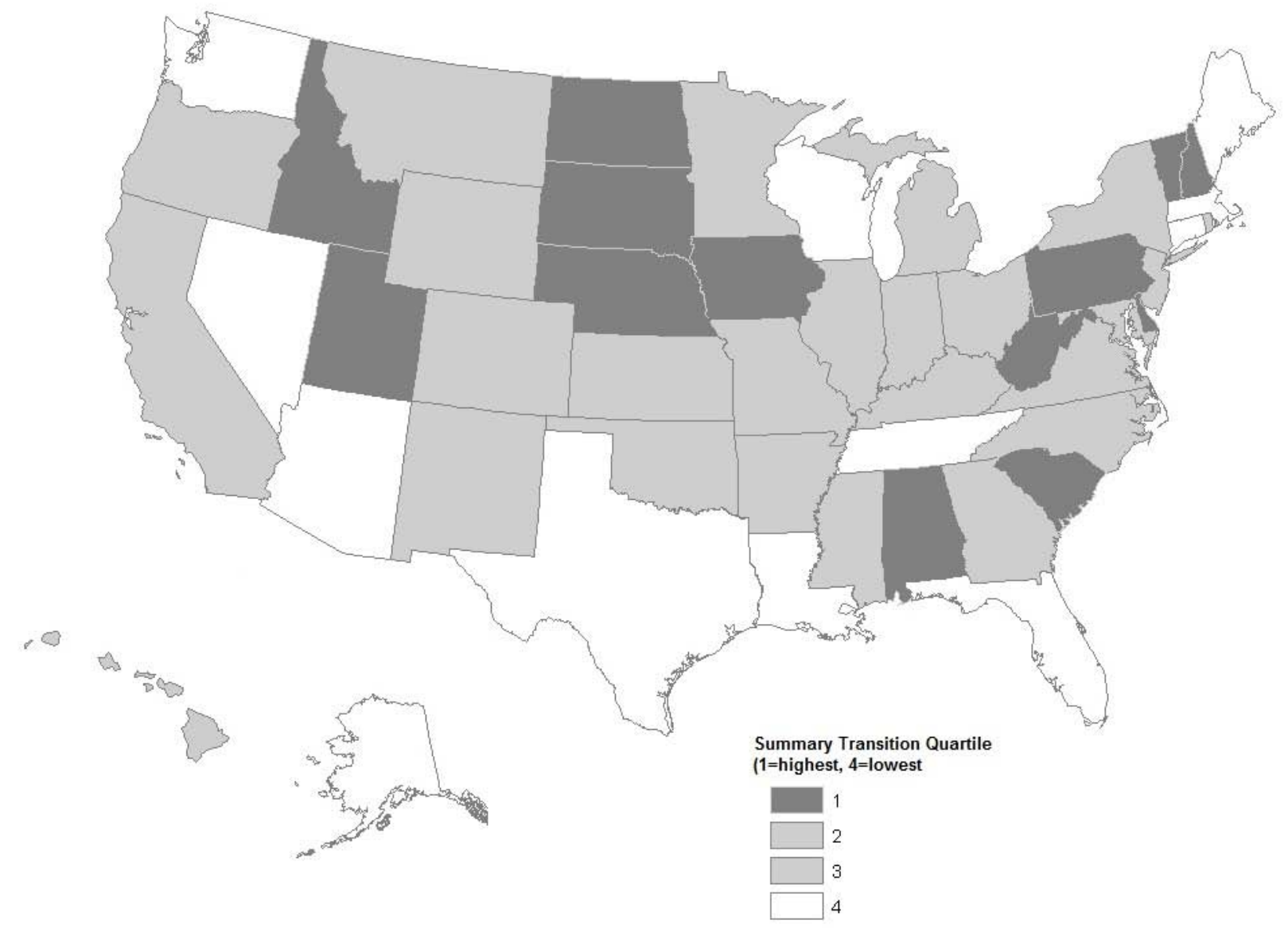

Sources: $\quad$ RSA-911 closure records, fiscal years 2004-2011; ACS 2004-2006.

Note: $\quad$ Data show the 2004, 2005, and 2006 proportions of transition-age youth with disabilities who received VR services and closed with an employment outcome (the product of the three transition-age youth ratios presented in Table III.4 in the main text). States are shaded by quartile, with the lowest proportions shaded dark gray and the highest proportions shaded white.

Several agency- and state-level factors, such as the unemployment rate and the amount of resources available to the VR agency, were correlated with the proportion of a state's youth with disabilities who applied for services. We found fewer factors to be associated with the service delivery and employment ratios, possibly because other factors that we could not observe may have 
been involved. Some financial factors - the mean cost of purchased services per individual served and order of selection status_-may limit an agency's ability to serve more youth.

Transition-age youth represent a substantial proportion-nearly one-third-of the population that VR agencies serve. Their unique vocational and education needs are one reason why many agencies focus on this population-for example, by having dedicated counselors and vocational programs specifically for youth. The best level of resources an agency should provide, however, is unknown. We have no information on the ideal amount of services or the proportion of youth with disabilities who VR agencies should serve. Therefore, the numbers presented in this study represent a first look at how agencies work with the transition-age population in their state.

If policymakers want to promote the services the transition-age population receives, they could develop specific standards and indicators for agencies regarding this population. Should RSA develop standards and guidelines for the transition-age population agencies serve, this study points out several limitations and challenges in such an approach. Further research is needed on agency practices that can influence the transition ratios presented in this study. 
This page has been left blank for double-sided copying. 


\section{INTRODUCTION}

State vocational rehabilitation (VR) agencies serve a critical role in helping transition-age youth (ages 16 to 24) with disabilities attain their vocational goals, by offering specific vocational training and providing funding for higher education. In principle, effective VR services can help young adults avoid seeking disability benefits or help those with benefits become more self-sufficient.

The knowledge about best practices for agencies in serving transition-age youth is insufficient, despite this population comprising about one-third of individuals seeking VR services. Ensuring successful work-related outcomes for this population is of high importance to policymakers and the disability community due to the persistent poor employment outcomes of transition-age youth with disabilities. However, the optimal level of services, supports, and outcomes for youth is unknown. Currently, although agencies have performance measures and goals related to the entire population served, no such measures or statistics are available for their transition-age populations. Youths' experiences with VR and their outcomes could be very different from the experiences and outcomes of the working-age (ages 25 to 64) population.

This paper attempts to add to the knowledge about state VR agency provision of services to transition-age youth by presenting new state-level statistics on the outcomes for youth who apply for VR services, obtained by merging RSA-911 closure data across several years. For comparison purposes, we also provide state-level statistics from other sources, most notably statistics for youth with disabilities from the American Community Survey. The study answers three questions: (1) At what rates do transition-age youth with disabilities apply to VR agencies? (2) Among those who apply, how likely is it that they will receive services? (3) What proportion of youth VR cases are closed with an employment outcome, and how does that compare with the employment rate for a state's entire population of transition-age youth with disabilities? We compare these answers across agencies and conduct a series of correlational analyses between these measures and agency- and state-level factors. This information could help inform considerations of performance measures for agencies in how they work with youth with disabilities, but also points to challenges and limitations in creating such measures.

We found that states had wide variation in how their VR agencies served their transition-age youth populations. The percentage of states' transition-age youth populations applying for VR services ranged from 4 to 14 percent, and agencies provided services to 31 to 82 percent of those applicants. Though 40 to 70 percent of youth who received VR services closed with an employment outcome, that ratio ranged from being substantially above to well below the employment rate of the state's youth with disabilities.

This paper is structured as follows. The next section presents issues related to how VR agencies serve transition-age youth with disabilities. Section II provides details about the data, measures, and methods used to answer this study's research questions. Section III offers the results of the study, including agency-level information on how each serves their transition-age youth population. The final section concludes with implications for policymakers and suggestions for future research.

\section{A. Poor Employment and Education Outcomes for Youth with Disabilities}

Employment outcomes and engagement in productive activities (such as school enrollment) for youth with disabilities are typically below those of youth without disabilities. For example, employment rates of youth and young adults with work limitations lagged behind youth without limitations by about 20 to 30 percentage points, using data from the Current Population Survey 
(CPS) (Horvath-Rose et al. 2004). In 2005, youth with disabilities aged 17 through 21 who were no longer in school had an employment rate of 57 percent, while their peers without disabilities had an employment rate of 66 percent (U.S. Department of Education 2010). Youth with limiting conditions had differences in an annual employment measure of about 10 to 12 percentage points below those of youth without health conditions or youth with nonlimiting conditions (Mann and Honeycutt, forthcoming). For youth with disabilities receiving Supplemental Security Income (SSI) benefits (a large portion of the population served by VR agencies), employment outcomes are lower than those observed for other youth with disabilities, in part because of their lower levels of human capital (Wittenburg and Loprest 2007).

These poor outcomes may reflect the barriers to employment faced by transition-age youth with disabilities. These youth often do not receive the same educational preparation as their peers without disabilities because they may be tracked into curricula that are not as rigorous as the standard curricula. If youth with disabilities are guided toward a less rigorous curricula than they are capable of pursuing, they could be left at potential educational and vocational disadvantages. Furthermore, a sizeable portion of transition-age youth with disabilities who receive special education services in secondary school settings (that is, served under IDEA Part B) fail to earn a high school diploma (U.S. Department of Education 2010). Additional barriers include a lack of appropriate work supports, challenges related to health, a lack of social networks that would aid them in identifying employment opportunities, and a lack of awareness of their rights to disability-related workplace accommodations (Rangarajan et al. 2009; Shandra and Hogan 2008).

\section{B. VR Agencies Can Help Youth Overcome Transition Barriers}

To overcome these barriers and achieve better transition outcomes, youth with disabilities often seek VR services. VR agencies are joint federal-state programs that assist those eligible for rehabilitation services in attaining employment. The agencies are required to collaborate with state education agencies to plan and deliver services to students with disabilities. Federal funding for VR agencies is provided through RSA, while state governments match the federal funds at a 21 percent rate (U.S. Department of Education 2012). When either federal or state funding is limited, agencies enter order of selection (OOS) status, serving only those eligible applicants with more severe disabilities (Silverstein 2010). To be eligible for VR services, applicants must meet the criteria set forth in the Rehabilitation Act of 1973 (that is, requiring vocational rehabilitation because of a disability) (U.S. Department of Education 2012). Not everyone who applies for VR services is assessed as eligible, and, among those found eligible, not all receive services. Some people found to be eligible fail to initiate VR services or are placed on waiting lists (for agencies operating under OOS), while others do not complete a plan for services. VR agencies have some latitude in determining the services they provide and the clientele they serve, resulting in state-level variation in VR program services, staffing, and expertise for youth with disabilities.

Not enough is known about best practices for VR agencies in serving their transition-age youth populations and obtaining better outcomes. The Study Group, Inc. (2007) identified gaps in services across agencies, such as not having processes to identify youth who did not have an individualized education program (IEP) in secondary school. It also recommended policies such as building interagency collaborations between the VR agency and state and local education programs, improving the identification and referral of eligible youth, and strengthening the data collection efforts for transition-age youth. However, none of these gaps or recommendations is supported by conclusive evidence of their effectiveness in promoting employment for transition-age youth. An extensive literature has shown the effectiveness of vocational and work-based experiences in promoting transition outcomes for youth with disabilities (Brewer et al. 2011; Carter et al. 2012; 
Fraker 2013; Shandra and Hogan 2008). Research on VR services has focused on the broader working-age population (for example, Dean et al. 2012); fewer studies have examined specific VR practices for youth. Much of this research has typically been small in scope (limited to a specific state or disability population) or limited in its comparisons of outcomes to an appropriate counterfactual (Benz et al. 1999; Gonzales et al. 2011; Hart et al. 2001). One exception is Berry and Caplan's (2010) examination of VR services for SSI youth: youth who received supported employment services through VR were more likely to be employed two years after completing services, whereas youth who received education services through VR were less likely to be employed but had higher earnings up to five years after completing VR services. This study also identified state contextual factors-the poverty rate and the agency consumer-to-counselor ratio-that influenced outcomes for youth SSI beneficiaries.

\section{Research Questions}

The current study answers three research questions to expand on the knowledge of how each VR agency serves youth with disabilities.

1. To what extent does each state's population of transition-age youth with disabilities apply for VR services?

2. Among those who apply, how likely is it that a transition-age youth will receive services?

3. What proportion of youth who receive VR services have their cases closed with an employment outcome, and how does that compare with the employment rate for the state's entire population of transition-age youth with disabilities?

This study answers these questions by exploring the variation in how VR agencies served transition-age youth with disabilities along these dimensions among those who applied for services from fiscal years 2004 to 2006. Each of these questions pertains to a stage of VR services: the level of outreach by the agency to youth and providers, the appropriateness of applications for service and the agency's ability to transition eligible applicants to service recipients, and the employment success of those served. Information on variation among VR agencies along these dimensions, along with consideration of other factors influencing that variation, could help RSA set standards for how agencies work with youth. 
This page has been left blank for double-sided copying. 


\section{METHODS}

\section{A. Data Sources}

This study used RSA-911 Case Service Report data for federal fiscal years 2004 through 2011 to develop application and closure cohort files for youth and young adults who applied for VR services in fiscal years 2004, 2005, and 2006. The RSA-911 data contain information about each person who exited VR services during the year, such as characteristics at application, types of services received, and employment outcomes for those who received services. States provide data on case closures by November for the previous fiscal year to RSA, which in turn releases the data to the public annually.

For the purpose of this study, we defined the transition-age youth population as those aged 16 to 24, inclusive, at the time they applied for VR services. We specified 24 years as the upper age limit to align with the definition of the working-age population (typically aged 25 to 64) and 16 years as the lower age limit to align with IDEA legislation on when secondary-school staff establish a transition plan. Only youth who had applied to VR agencies that serve the general population of the 50 states and the District of Columbia were included in the analysis. We excluded applicants to agencies that exclusively serve the blind (approximately 3 percent of all closures). Furthermore, our sample includes only individuals who were alive at the time of case closure. To develop applicant cohorts that follow youth from application to case closure, we realigned the data to include only youth who applied for VR services in fiscal years 2004, 2005, and 2006. This realignment allows sufficient time through 2011 (five to seven years) to observe their completion of VR services. It also has the added value of comparing the experiences of youth who applied at about the same time, thereby controlling for local, state, and agency factors that could vary for individuals who close at the same time (most notably for those who close with and without receiving VR services).

To supplement the RSA-911 data, the analysis draws from additional RSA data sources (2004 VR state plans, RSA-2, and RSA-113) to obtain agency-specific variables. We calculated state-level estimates of the number of youth with disabilities using the American Community Survey (ACS) from 2004 through 2006, identifying youth with hearing impairments, vision impairments, physical disabilities, mental disabilities, self-care disabilities, and independent-living limitations (U.S. Census Bureau 2006).

We used IDEA Part B Child Count data for 2004 through 2006 to identify the annual number of youth in each state aged 16 to 21 who received special education services. Data from the VR Transition Study provided information on whether the agency had a state- or regional-level transition coordinator, whether any VR counselors had dedicated caseloads of transition-age youth, and the proportion of counselors with dedicated transition-age youth caseloads (The Study Group, Inc. 2007). Our study makes use of state-level, seasonally adjusted, annual unemployment data from the June CPS for 2004 through 2006. Finally, we include a funding ratio that compared the state 2008 VR federal funding with the number of working-age individuals with disabilities in the state while adjusting for variation across states in service and wage costs (GAO 2009). Though it lies

outside the time frame of the application years, this ratio reflects a measure of the relative amount of resources the state receives to serve its population with disabilities, assuming that cross-state variation in the values that inform the ratio (state costs, federal funding, and the population with disabilities) was similar during the study period. 


\section{B. Measures}

Transition-age youth ratios. The primary focus of our analysis is an assessment of each VR agency's involvement with transition-age youth as reflected in the following four ratios calculated for each agency:

1. Applicant ratio (ratio of VR youth applicants to the number of youth with disabilities). This ratio's numerator, from the RSA-911 data for 2004 to 2006 applicants, represents the flow of individuals into a VR agency. The denominator, based on ACS data, is an estimate of the state population of youth with disabilities. This represents the stock of youth who could potentially seek VR services, though some portion of them will have already been involved with VR. The ratio of these two measures is indicative of how well youth knew about and sought VR services, as well as the extent to which service providers (particularly secondary schools) referred youth with disabilities to VR agencies.

2. Service ratio (ratio of youth who received VR services to youth who applied). Both the numerator and the denominator of this ratio come from the RSA-911 data for 2004 to 2006 applicants. Because the numerator includes only individuals who were assessed as eligible, completed an IEP, and eventually received services from the agency, this ratio captures both eligibility of applicants for VR services and the service take-up rate. The ratio shows the proportion of youth who applied for VR services whose applications were accepted and who subsequently received the offered services.

3. Employment ratio (ratio of youth with positive employment outcomes to youth who received services). The third ratio uses a similar approach as the service ratio, with both the numerator and the denominator constructed from the RSA-911 data for 2004 to 2006 applicants. The denominator is the same as the numerator for the service ratio; the numerator is the subset of that population who closed from services with employment (as opposed to those not employed at closure). The ratio indicates the proportion of youth who achieved positive employment outcomes at closure out of those who received services. Note, though, that some employment of youth applicants is not captured in the RSA-911 data because those youth obtained jobs without obtaining services and their cases were closed in another category, or they obtained jobs after closure.

4. Relative employment ratio. In addition to the issues mentioned above, the employment ratio does not account for the state's economic environment, which could influence employment outcomes. Mindful of these limitations, we compared the VR employment ratio with the employment rate of all youth with disabilities in the state (derived from the ACS). The employment ratio is the numerator and the state employment rate for youth with disabilities is the denominator. To estimate a state employment rate independent of those involved with VR, the denominator excludes youth who received VR services and who closed with employment by subtracting the RSA numbers from the ACS numbers. This approach controls for state environmental characteristics that could result in relatively high or low employment outcomes with inappropriate attributions to VR agency services if we were to look at the VR youth employment rate in isolation. To maintain comparability with the ACS, the numerator represents VR case closures in 2004, 2005, and 2006, rather than applicants in those years. 
The above ratios capture agency involvement at distinct stages in their work with transition-age youth and are comparable across agencies. The first three ratios are calculated for each application cohort, while the fourth ratio is calculated for each closure cohort; all four are then averaged across the three cohort years. Though population-based denominators for the second and third ratios are available, they are unavailable for the first and fourth measures. For these, the sample-based ACS disability estimates represent the population eligible to apply for and receive VR services, though these estimates are likely inaccurate because the ACS disability definition and the VR agency eligibility definitions differ. The ACS disability questions identify anyone with a self-reported limitation and do not fully capture all individuals with a work-limiting disability (Burkhauser et al. 2012). VR agencies, on the other hand, have a narrower definition of disability eligibility, at least administratively: individuals must have an impairment that impedes their ability to work and the individual requires VR services to achieve employment goals (though in practice, adherence to these standards may vary) (U.S. Department of Education 2012). A youth could therefore respond positively to having a disability in the ACS, yet not qualify for VR services.

Agency- and state-level measures. To supplement the analysis, we also included a variety of agency- and state-level statistics to determine whether they can partially account for variation in the state-level ratios regarding transition-age youth.

- Volume factors: The state's transition-age youth population (the number and the proportion of the state's population; ACS), the proportion of a state's transition-age youth population with a disability (ACS), the proportion of youth receiving special education services (OSEP), and the number of VR applicants of all ages (RSA-911).

- Agency resource factors: The cost of purchased services per individual served (RSA911), the proportion of an agency's funds spent on postsecondary education (regardless of age; RSA-2), the ratio of applicants to counselors (RSA-2), the 2008 VR grant allotment per working-age person with a disability in the state (GAO 2009), and whether the agency was in order of selection (OOS) and had a wait list for services (categories include no OOS, OOS with no wait list, OOS with 1 to 9 percent of applicants on a wait list, OOS with 10 to 49 percent of applicants on a wait list, and OOS with 50 percent or more of applicants on a wait list) (RSA-113).

- Focus on transition-age youth: Whether VR agencies had goals and programs for transition-age youth (from the 2004 state plans), dedicated state transition leadership, VR counselors with dedicated transition caseload, and the percentage of counselors with a transition caseload (each from the VR Transition Study).

- VR client characteristics: The percentage of transition-age VR clients who were referred by high schools or postsecondary institutions, the percentage with individualized education programs, and the percentage who were employed at the time of their application for VR services (RSA-911).

- State economic environment: The state-level annual unemployment rate (CPS) and the state-level labor force participation rate for all transition-age youth (ACS).

As with the transition-age youth ratios, three-year averages for these measures were calculated when multiple years of data were available. OOS reflects the maximum wait list value observed during the three-year period. 


\section{Analytical Approach}

The analysis relies on two approaches to explore the variation in how VR agencies work with transition-age youth. The first approach involves agency-specific values for the four transition-age youth ratios. This approach enables us to see the range of values across agencies and the agencies with relatively high or low values for these ratios. We also calculated a summary statistic by multiplying the first three ratios (application, service, and employment) together. This statistic ("the proportion of youth with disabilities who closed from VR with employment") provides a measure of the likelihood that a transition-age youth with a disability would seek and receive VR services and then obtain employment. High values on this measure indicate states in which the VR agency both served a large proportion of transition-age youth with disabilities and recorded positive employment outcomes for many of them. Relatively low values, on the other hand, identify states in which the VR agency served relatively few transition-age youth with disabilities and/or those served were not recorded as employed at case closure. The second approach extends the first approach by systematically comparing agency- and state-level factors with the four ratios and summary statistic using Pearson correlation coefficients statistical tests. Given the small sample size (51 states), this analysis is exploratory in nature, and the results are presented as a starting point for future research. 


\section{RESULTS}

\section{A. Descriptive Statistics}

The characteristics of the transition-age population seeking services may underlie the decisions an agency makes in serving transition-age youth. Table III.1 presents descriptive statistics across VR agencies on the individual characteristics of their transition-age youth who applied for VR services, including a measure of standardized variation to show the uniform variation of each characteristic. ${ }^{1}$ These data indicate the considerable variation that occurs across VR agencies regarding the population seeking services, particularly around race and referral source categories. For educational attainment at application, the proportion of transition-age youth who had less than a high school diploma ranged from 31 to 81 percent. The range for the percentage of applicants who were referred from elementary and secondary institutions was 15 to 65 percent, and the proportion of applicants who had IEPs ranged from 23 to 87 percent (perhaps a reflection of youth applicants still in high school).

The variation on some of these factors can be explained by the degree to which VR agencies coordinated with state and local education officials. In Maine, for example, 81 percent of transitionage applicants for VR services had not attained a high school diploma, 83 percent had an IEP, and 59 percent were referred from a primary or secondary school, all of which are indicative of strong ties between the VR agency and the educational system. At the other end of the spectrum, most applicants to the agency in Utah held at least a high school diploma (69 percent), and 85 percent were referred by sources other than primary or secondary school, whereas only 33 percent had an IEP. The pattern found in Utah suggests a service approach of working with youth when they leave secondary schools.

The proportion of a state's VR applicant pool that received federal disability benefits (SSI or SSDI) at application ranged from 10 to 44 percent. Relative to nonbeneficiaries, these individuals may face more employment barriers by virtue of having more significant disabilities and relatively low human capital (Wittenburg and Loprest 2007). The distribution of disability type varied as well. In most states, the majority of applicants had an intellectual disability as the primary disability, followed by psychiatric, physical, and sensory conditions. However, these patterns are not consistent across agencies. For example, the proportion of transition-age youth who applied for VR services and had a psychiatric disability surpassed the proportion with an intellectual disability in three states (Florida, South Carolina, and Utah).

Tables III.2 and III.3 present descriptive statistics for the agency- and state-level factors, and they show considerable variation in these characteristics. The largest standardized variation occurred with the number of transition-age youth, the number of VR applicants, and the percentage of service expenditures related to postsecondary education. The proportion of a state's transition-age youth population with disabilities ranged from 4.5 to 10.8 percent, the mean cost of purchased VR services

\footnotetext{
${ }^{1}$ Complete state-level data for Tables 1, 2, and 3 can be found in Appendix A.
} 
Table III.1. Descriptive Statistics of the Individual Characteristics of VR Applicants Aged 16 to 24, 2004-2006

\begin{tabular}{|c|c|c|c|c|c|c|}
\hline Variable & Mean & $\begin{array}{l}\text { Standard } \\
\text { Deviation }\end{array}$ & $\begin{array}{l}\text { Standardized } \\
\text { Variation }\end{array}$ & Median & Minimum & Maximum \\
\hline Female (\%) & 40.7 & 2.5 & 0.1 & 40.5 & 33.4 & 46.1 \\
\hline \multicolumn{7}{|l|}{ Race (\%) } \\
\hline White-only & 74.0 & 18.5 & 0.3 & 77.3 & 8.2 & 97.4 \\
\hline African American-only & 19.5 & 18.8 & 1.0 & 14.2 & 0.7 & 89.8 \\
\hline American Indian-only & 2.4 & 4.0 & 1.7 & 0.7 & 0.1 & 19.0 \\
\hline Asian-only & 1.6 & 4.6 & 2.9 & 0.6 & 0.1 & 33.4 \\
\hline \multicolumn{7}{|l|}{ Native Hawaiian/other Pacific } \\
\hline Islander-only & 1.0 & 5.3 & 5.3 & 0.2 & 0.0 & 37.9 \\
\hline Multi or Biracial & 1.4 & 1.3 & 0.9 & 1.0 & 0.0 & 6.4 \\
\hline Missing & 0.2 & 0.6 & 3.0 & 0.0 & 0.0 & 3.5 \\
\hline Hispanic or Latino (any race) & 8.4 & 10.9 & 1.3 & 3.3 & 0.4 & 56.8 \\
\hline Average Age at Closure (mean) & 20.9 & 0.4 & 0.0 & 20.8 & 20.1 & 22.3 \\
\hline \multicolumn{7}{|l|}{$\begin{array}{l}\text { Educational Attainment at } \\
\text { Application (\%) }\end{array}$} \\
\hline Less than high school & 61.6 & 11.7 & 0.2 & 62.1 & 30.5 & 80.8 \\
\hline High school graduate & 29.4 & 10.4 & 0.4 & 27.2 & 14.4 & 62.2 \\
\hline Postsecondary & 8.7 & 3.0 & 0.3 & 8.3 & 3.0 & 17.2 \\
\hline Missing & 0.3 & 0.8 & 2.7 & 0.0 & 0.0 & 4.0 \\
\hline \multicolumn{7}{|l|}{ Individualized Education } \\
\hline Program (\%) & 59.4 & 17.5 & 0.3 & 60.7 & 22.9 & 87.1 \\
\hline \multicolumn{7}{|l|}{ Referral Source (\%) } \\
\hline $\begin{array}{l}\text { Educational institution } \\
\text { (elementary/ secondary) }\end{array}$ & 45.1 & 12.4 & 0.3 & 46.7 & 14.9 & 65.4 \\
\hline \multicolumn{7}{|l|}{ Educational institution } \\
\hline (postsecondary) & 4.4 & 2.6 & 0.6 & 4.2 & 0.0 & 12.3 \\
\hline Medical personnel & 5.1 & 3.4 & 0.7 & 4.7 & 0.4 & 19.8 \\
\hline Welfare agency & 2.2 & 1.8 & 0.8 & 1.7 & 0.3 & 7.2 \\
\hline \multicolumn{7}{|l|}{ Community rehabilitation } \\
\hline programs & 4.9 & 4.1 & 0.8 & 3.7 & 0.2 & 21.3 \\
\hline Social Security Administration & 0.7 & 0.3 & 0.4 & 0.6 & 0.1 & 1.5 \\
\hline One-Stop employment center & 1.5 & 1.0 & 0.7 & 1.4 & 0.0 & 4.7 \\
\hline Self & 16.0 & 4.9 & 0.3 & 16.1 & 5.7 & 25.8 \\
\hline Other & 19.9 & 8.0 & 0.4 & 18.2 & 7.7 & 41.9 \\
\hline Missing & 0.1 & 0.6 & 6.0 & 0.0 & 0.0 & 3.1 \\
\hline \multicolumn{7}{|l|}{ Disability Type (\%) } \\
\hline Sensory & 5.8 & 2.5 & 0.4 & 5.4 & 2.2 & 14.2 \\
\hline Physical & 11.7 & 5.1 & 0.4 & 10.2 & 5.8 & 32.5 \\
\hline Intellectual & 51.7 & 10.2 & 0.2 & 53.6 & 26.1 & 70.1 \\
\hline Psychiatric & 25.0 & 7.6 & 0.3 & 24.2 & 10.8 & 47.2 \\
\hline None & 1.2 & 2.2 & 1.8 & 0.1 & 0.0 & 9.0 \\
\hline Missing & 4.5 & 6.8 & 1.5 & 0.7 & 0.0 & 23.8 \\
\hline SSI or SSDI at application (\%) & 21.3 & 6.2 & 0.3 & 21.1 & 9.8 & 43.6 \\
\hline
\end{tabular}

Source: $\quad$ RSA-911 closure records, fiscal years 2004 through 2011.

Note: $\quad \mathrm{N}=51$. Table shows descriptive statistics across VR agencies of the selected characteristics of youth aged 16 to 24 who applied for VR services in 2004, 2004, or 2006. Standardized variation is the value of the standard deviation divided by the mean. 
Table III.2. Characteristics of States and State VR Agencies, 2004-2006

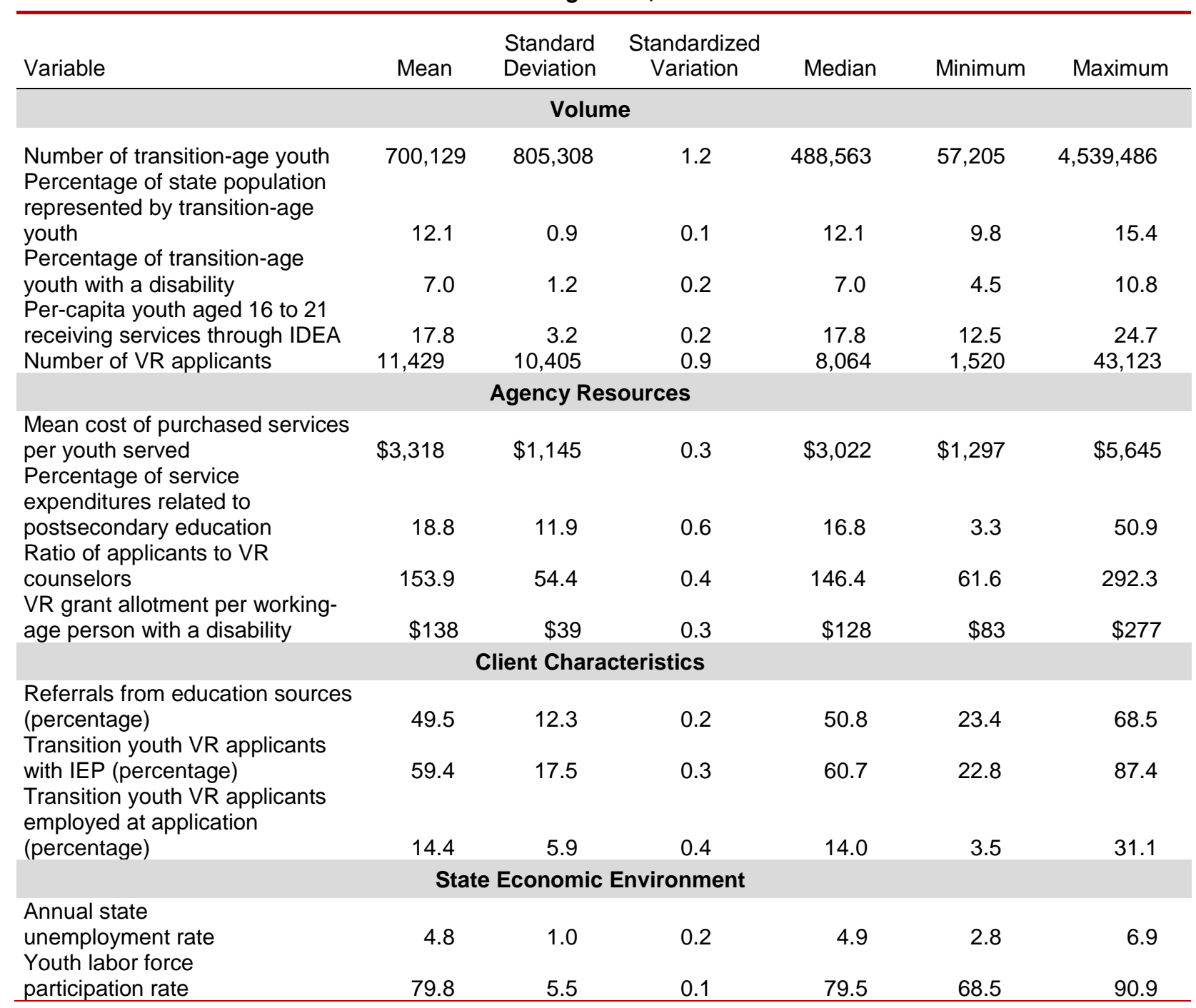

Source: $\quad$ RSA-911 closure records, fiscal years 2004 through 2011; ACS 2004-2006; other sources as defined in the methods section.

Note: $\quad \mathrm{N}=51$. Table shows descriptive statistics across state agencies of the three-year averages of agencyand state-level variables. Standardized variation is the value of the standard deviation divided by the mean. 
Table III.3. Transition Staff and Order of Selection Characteristics of State VR Agencies, 2004-2006

\begin{tabular}{|c|c|c|}
\hline Variable & $\mathrm{N}$ & Percentage \\
\hline \multicolumn{3}{|l|}{ Focus on Transition-Age Youth } \\
\hline Had goals and programs related to youth in state plan & 13 & $26 \%$ \\
\hline Had dedicated state transition leadership & 43 & $88 \%$ \\
\hline Had VR counselors with dedicated transition caseload & 37 & $76 \%$ \\
\hline \multicolumn{3}{|l|}{ Percentage of counselors with dedicated transition caseloads } \\
\hline $0 \%$ & 12 & $24 \%$ \\
\hline $1 \%-5 \%$ & 14 & $29 \%$ \\
\hline $6 \%-10 \%$ & 6 & $12 \%$ \\
\hline $11 \%-15 \%$ & 6 & $12 \%$ \\
\hline $16 \%-20 \%$ & 4 & $8 \%$ \\
\hline $21 \%$ or more & 7 & $14 \%$ \\
\hline \multicolumn{3}{|l|}{ Agency Resources } \\
\hline No OOS & 20 & $39 \%$ \\
\hline OOS, no wait list & 11 & $22 \%$ \\
\hline OOS, 1 to 9 percent on wait list & 8 & $16 \%$ \\
\hline OOS, 10 to 49 percent on wait list & 3 & $6 \%$ \\
\hline OOS, 50 percent or more on wait list & 9 & $18 \%$ \\
\hline
\end{tabular}

Sources: $\quad$ Study Group National Survey, 2006; RSA-113, fiscal years 2004 through 2006.

Note: $\quad \mathrm{N}=51(\mathrm{~N}=49$ for state transition leadership and dedicated transition counselor variables, and $\mathrm{N}=50$ for state plan data due to missing data).

per case ranged from $\$ 1,300$ to $\$ 5,600$, and the VR grant allotment per working-age person with a disability ranged from $\$ 83$ to $\$ 277$ (Table III.2). Findings from the assessment of VR agency state plans (Table III.3) show that 13 agencies had a focus on their transition populations (per their state plans), whereas 43 had dedicated state transition leadership (an official with statewide responsibilities for transition-age youth) and 37 had counselors with a dedicated transition caseload.

\section{B. VR Agency Transition-Age Youth Ratios}

We present data for the five transition-age youth measures in Table III.4 and discuss our findings for each below. It is important to emphasize that the statistics presented here represent an initial examination of how agencies work with transition-age youth. Values that are high or low do not indicate better or worse performance, as a number of factors outside of an agency's control can influence these statistics.

Applicant ratio. On average each year over the period 2004 through 2006, 8 percent of U.S. youth with disabilities aged 16 to 24 applied for VR services. Figure III.1 provides a graphical display of the application ratios for the VR agencies in Table III.4. Agencies with ratios in the middle two quartiles are shaded blue, while those with the more extreme ratios are white. The agencies are displayed in order, from lowest ratio to highest. The ratio ranged from 4 percent in Connecticut, Washington, and Alaska, to 14 percent in Iowa and North Dakota.

Service ratio. Across the United States, 56 percent of transition-age youth who applied for VR services eventually received them (Table III.4). However, as displayed graphically in Figure III.2, the VR agencies had a range of 51 percentage points for this ratio. At one end of the spectrum, 31 percent of youth in Tennessee and 36 percent of youth in Missouri who applied for services received them. At the other end, 82 percent of Alabama's youth applicants received services. One possible 
explanation for the low proportions observed in Tennessee and Missouri is that both operated under OOS and had long wait lists for services during the observation period.

Figure III.1. Applicant Ratio (Ratio of VR Youth Applicants to the State Population of Youth with Disabilities), by State

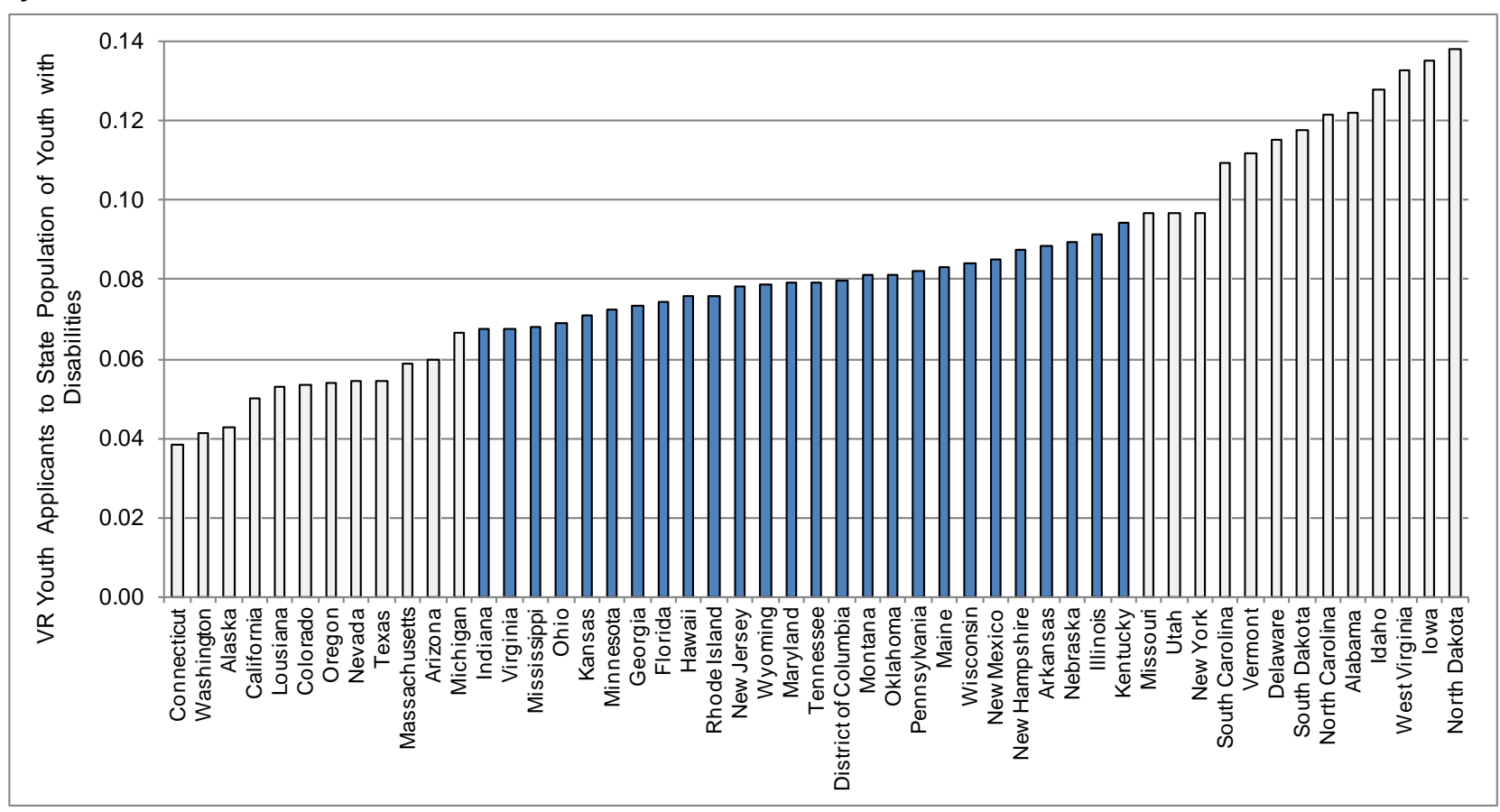

Sources: $\quad$ RSA-911 closure records, fiscal years 2004 through 2011; ACS 2004-2006.

Note: Data show the average ratio in 2004, 2005, and 2006 of the number of applicants to VR agencies aged 16 to 24 (numerator) and the average number of youth aged 16 to 24 with a disability, as identified in the ACS (denominator). State VR agencies are ordered from lowest to highest. Bars that are not shaded indicate the agencies in the top and bottom quartiles of the distribution. 
Table III.4. State VR Agency Transition Ratios and Comparative Assessments for Youth Aged 16 to 24

\begin{tabular}{|c|c|c|c|c|c|c|}
\hline \multirow[b]{2}{*}{ State Agency } & \multicolumn{4}{|c|}{ Transition Ratios } & \multirow{2}{*}{$\begin{array}{c}\text { Proportion of } \\
\text { Youth Who } \\
\text { Closed from VR } \\
\text { with } \\
\text { Employment }\end{array}$} & \multirow[b]{2}{*}{$\begin{array}{c}\text { Quartile } \\
\text { Ranking (1 is } \\
\text { highest) }\end{array}$} \\
\hline & $\begin{array}{c}\text { Applicant } \\
\text { Ratio } \\
\end{array}$ & Service Ratio & $\begin{array}{c}\text { Employment } \\
\text { Ratio } \\
\end{array}$ & $\begin{array}{c}\text { Relative } \\
\text { Employment } \\
\text { Ratio } \\
\end{array}$ & & \\
\hline Alabama & 0.12 & 0.82 & 0.65 & 1.18 & 0.065 & 1 \\
\hline Alaska & 0.04 & 0.58 & 0.57 & 0.78 & 0.014 & 4 \\
\hline Arizona & 0.06 & 0.53 & 0.47 & 0.67 & 0.015 & 4 \\
\hline Arkansas & 0.09 & 0.56 & 0.61 & 0.90 & 0.031 & 2 \\
\hline California & 0.05 & 0.63 & 0.56 & 1.03 & 0.018 & 3 \\
\hline Colorado & 0.05 & 0.57 & 0.69 & 0.92 & 0.021 & 3 \\
\hline Connecticut & 0.04 & 0.52 & 0.47 & 0.75 & 0.010 & 4 \\
\hline Delaware & 0.12 & 0.72 & 0.66 & 0.90 & 0.055 & 1 \\
\hline District of Columbia & 0.08 & 0.49 & 0.59 & 1.01 & 0.023 & 3 \\
\hline Florida & 0.07 & 0.49 & 0.47 & 0.82 & 0.017 & 4 \\
\hline Georgia & 0.07 & 0.70 & 0.57 & 0.92 & 0.029 & 2 \\
\hline Hawaii & 0.08 & 0.66 & 0.44 & 0.76 & 0.022 & 3 \\
\hline Idaho & 0.13 & 0.58 & 0.62 & 0.77 & 0.046 & 1 \\
\hline Illinois & 0.09 & 0.46 & 0.63 & 0.97 & 0.027 & 2 \\
\hline Indiana & 0.07 & 0.56 & 0.48 & 0.66 & 0.018 & 3 \\
\hline lowa & 0.14 & 0.44 & 0.66 & 0.83 & 0.039 & 1 \\
\hline Kansas & 0.07 & 0.54 & 0.52 & 0.67 & 0.020 & 3 \\
\hline Kentucky & 0.09 & 0.51 & 0.62 & 1.19 & 0.030 & 2 \\
\hline Louisiana & 0.05 & 0.43 & 0.40 & 0.99 & 0.009 & 4 \\
\hline Maine & 0.08 & 0.41 & 0.44 & 0.61 & 0.015 & 4 \\
\hline Maryland & 0.08 & 0.48 & 0.67 & 1.17 & 0.025 & 2 \\
\hline Massachusetts & 0.06 & 0.54 & 0.56 & 0.96 & 0.018 & 4 \\
\hline Michigan & 0.07 & 0.67 & 0.48 & 0.84 & 0.022 & 3 \\
\hline Minnesota & 0.07 & 0.40 & 0.63 & 0.83 & 0.019 & 3 \\
\hline Mississippi & 0.07 & 0.60 & 0.63 & 1.16 & 0.026 & 2 \\
\hline Missouri & 0.10 & 0.36 & 0.69 & 0.94 & 0.024 & 2 \\
\hline Montana & 0.08 & 0.42 & 0.58 & 0.73 & 0.020 & 3 \\
\hline Nebraska & 0.09 & 0.63 & 0.62 & 0.83 & 0.034 & 1 \\
\hline Nevada & 0.05 & 0.52 & 0.60 & 0.90 & 0.017 & 4 \\
\hline New Hampshire & 0.09 & 0.63 & 0.66 & 0.87 & 0.036 & 1 \\
\hline New Jersey & 0.08 & 0.51 & 0.64 & 1.00 & 0.026 & 2 \\
\hline New Mexico & 0.08 & 0.53 & 0.51 & 0.75 & 0.023 & 3 \\
\hline New York & 0.10 & 0.55 & 0.57 & 0.95 & 0.030 & 2 \\
\hline North Carolina & 0.12 & 0.57 & 0.45 & 0.74 & 0.032 & 2 \\
\hline North Dakota & 0.14 & 0.49 & 0.68 & 0.82 & 0.047 & 1 \\
\hline Ohio & 0.07 & 0.51 & 0.52 & 0.82 & 0.018 & 3 \\
\hline Oklahoma & 0.08 & 0.61 & 0.45 & 0.45 & 0.022 & 3 \\
\hline Oregon & 0.05 & 0.51 & 0.65 & 0.97 & 0.018 & 3 \\
\hline Pennsylvania & 0.08 & 0.70 & 0.59 & 0.94 & 0.034 & 1 \\
\hline Rhode Island & 0.08 & 0.51 & 0.62 & 0.82 & 0.024 & 2 \\
\hline South Carolina & 0.11 & 0.68 & 0.56 & 1.01 & 0.041 & 1 \\
\hline South Dakota & 0.12 & 0.52 & 0.57 & 0.72 & 0.035 & 1 \\
\hline Tennessee & 0.08 & 0.31 & 0.53 & 1.22 & 0.013 & 4 \\
\hline Texas & 0.05 & 0.53 & 0.45 & 0.65 & 0.013 & 4 \\
\hline Utah & 0.10 & 0.56 & 0.69 & 0.77 & 0.037 & 1 \\
\hline Vermont & 0.11 & 0.69 & 0.59 & 0.72 & 0.045 & 1 \\
\hline Virginia & 0.07 & 0.67 & 0.54 & 0.75 & 0.025 & 2 \\
\hline Washington & 0.04 & 0.43 & 0.55 & 0.70 & 0.010 & 4 \\
\hline West Virginia & 0.13 & 0.56 & 0.65 & 1.04 & 0.048 & 1 \\
\hline Wisconsin & 0.08 & 0.45 & 0.44 & 0.63 & 0.017 & 4 \\
\hline Wyoming & 0.08 & 0.51 & 0.70 & 0.82 & 0.028 & 2 \\
\hline National & 0.08 & 0.56 & 0.56 & 0.86 & 0.023 & \\
\hline Mean & 0.08 & 0.55 & 0.57 & 0.86 & 0.026 & \\
\hline Standard deviation & 0.03 & 0.10 & 0.08 & 0.16 & 0.012 & \\
\hline Median & 0.08 & 0.53 & 0.58 & 0.83 & 0.024 & \\
\hline Minimum & 0.04 & 0.31 & 0.40 & 0.45 & 0.009 & \\
\hline Maximum & 0.14 & 0.82 & 0.70 & 1.22 & 0.065 & \\
\hline Range & 0.10 & 0.51 & 0.31 & 0.77 & 0.056 & \\
\hline
\end{tabular}

Sources: $\quad$ RSA-911 closure records, fiscal years 2004 through 2011; ACS 2004-2006. 
Table III.4 (continued)

Note: $\quad$ Data show three-year averages of 2004-2006 applicant cohorts or 2004-2006 closure cohorts, as defined in the methods section. Applicant ratio is the number of applicants to a VR agency aged 16 to 24 divided by the estimated number of youth aged 16 to 24 in the state. Service ratio is the number of youth aged 16 to 24 who received services from a VR agency relative to the number of applicants aged 16 to 24. Employment ratio is the number of youth aged 16 to 24 who closed from VR with employment outcomes relative to the number who received services. Relative employment ratio shows the employment ratio relative to the estimated employment rate of youth with disabilities in the state (after accounting for youth who received VR services, as detailed in the method section). Proportion of youth who closed from VR with employment is the product of the applicant, service, and employment ratios. Quartile ranking shows the quartile of the proportion of youth who closed from VR with employment, with 1 showing agencies in the highest quartile and 4 showing the lowest.

Figure III.2. Service Ratio (Ratio of Youth Who Receive VR Services Among Those Who Apply), by State

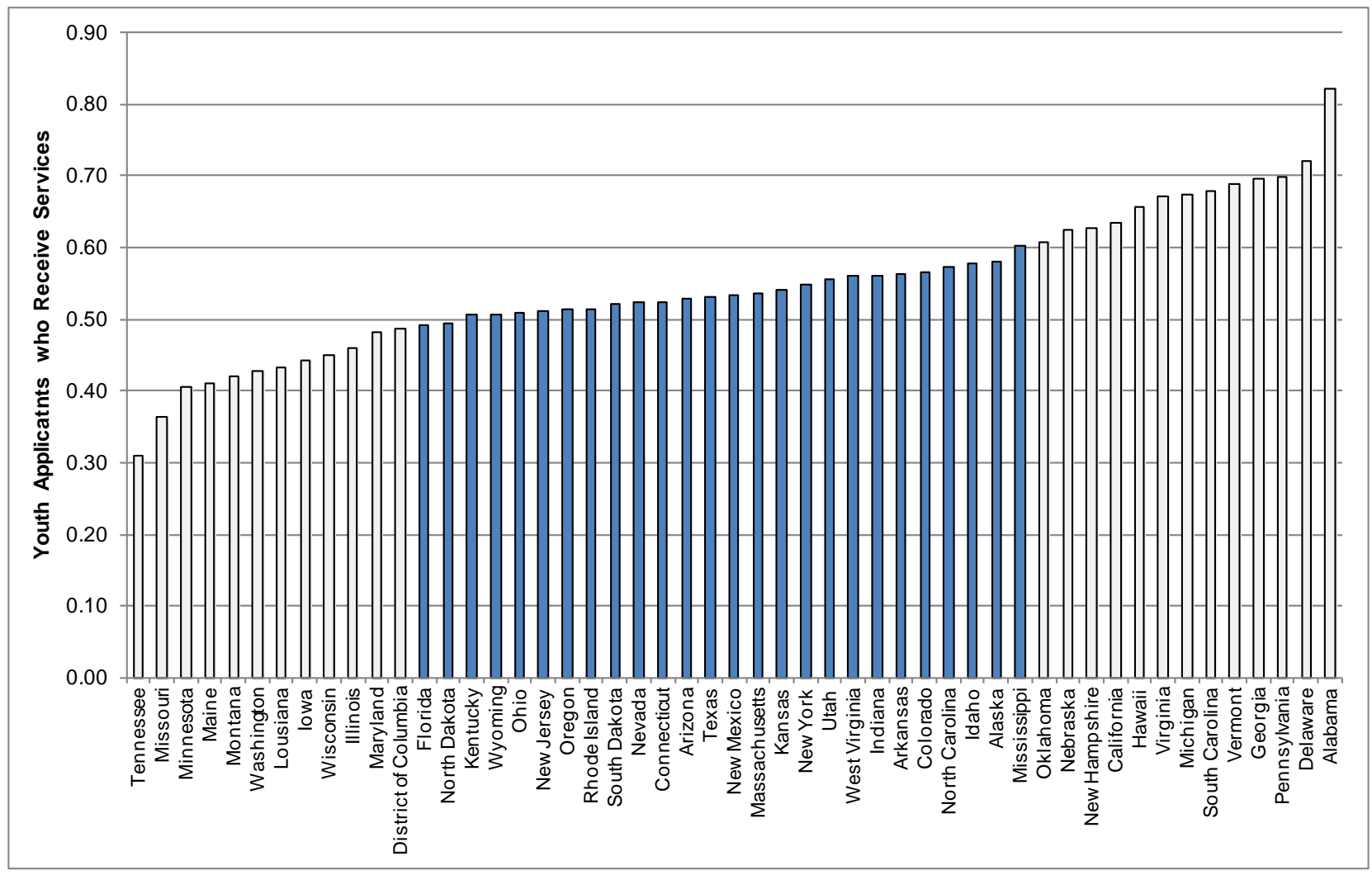

Source: $\quad$ RSA-911 closure records, fiscal years 2004 through 2011.

Note: $\quad$ Data show the average ratio in 2004, 2005, and 2006 of the average number of individuals aged 16 to 24 who eventually received services (numerator) among those who applied to VR agencies (denominator). State VR agencies are ordered from lowest to highest. Bars that are not shaded indicate the agencies in the top and bottom quartiles of the distribution.

Employment ratio. Nationally, of transition-age youth with disabilities who applied over the period 2004 through 2006 and received services, 56 percent closed their cases and were employed at the time they closed from VR. Agency data are displayed in Figure III.3. The VR agency in Wyoming had the highest employment ratio, with 70 percent of transition-age youth who applied exiting with employment. The Wyoming agency was closely followed by agencies in Colorado, Missouri, and Utah, all at 69 percent. On the low end, applicants to the VR agency in Louisiana were successful at achieving positive employment outcomes 40 percent of the time. The employment 
measure focuses on the proportion of applicants who received services and whose cases were closed with employment outcomes. This measure, however, can be influenced by economic and other conditions in the states.

Figure III.3. Employment Ratio (Ratio of VR Youth with Positive Employment Outcomes to Youth Served), by State

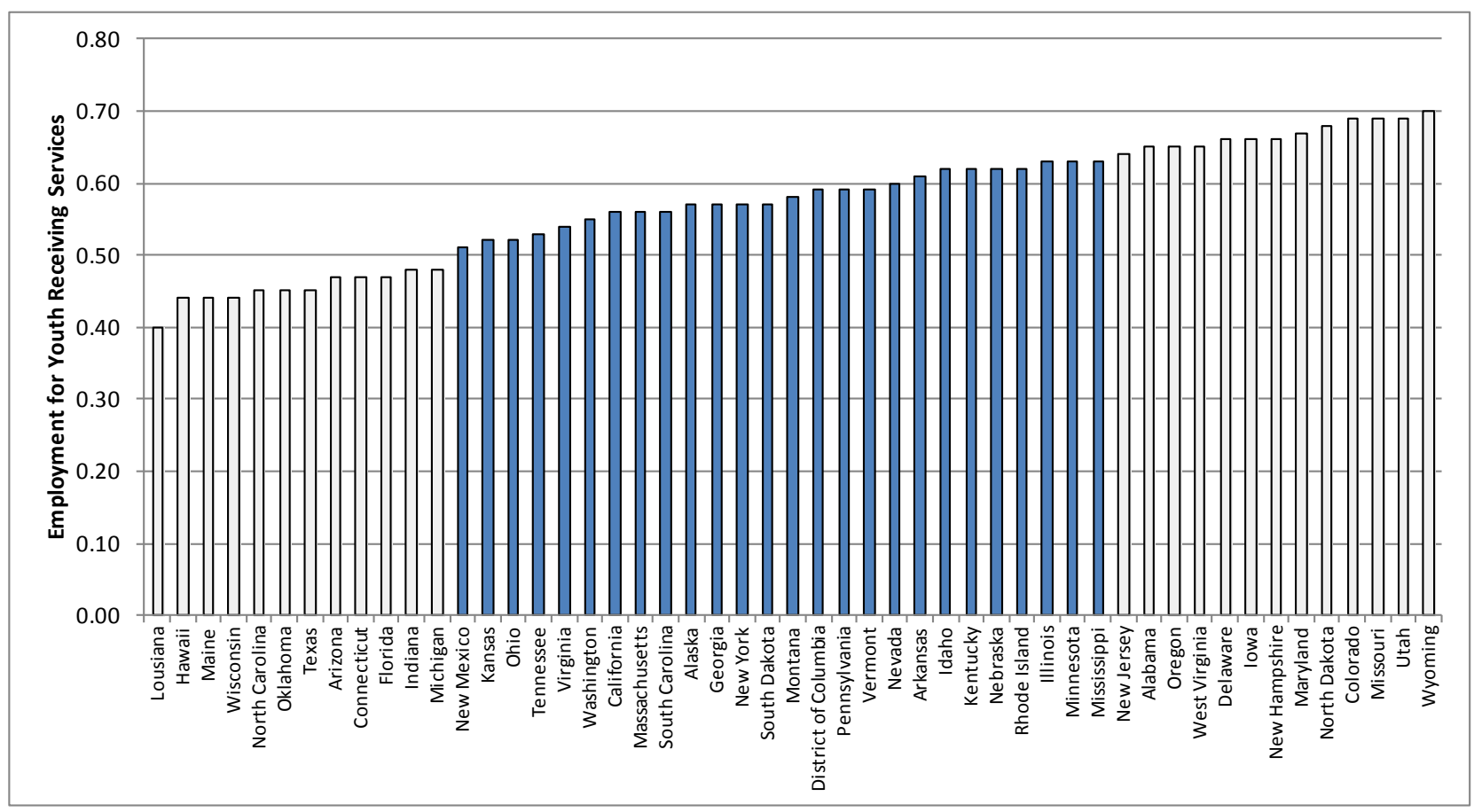

Source: $\quad$ RSA-911 closure records, fiscal years 2004 through 2011.

Note: $\quad$ Data show the average ratio in 2004, 2005, and 2006 of the number of individuals aged 16 to 24 who closed from VR with employment relative to the number who eventually received services (numerator) among those who applied to VR agencies (denominator). State VR agencies are ordered from lowest to highest. Bars that are not shaded indicate the agencies in the top and bottom quartiles of the distribution.

Relative employment ratio. To adjust for influences external to the VR agency in the ratio of youth who became employed and received services, we normalized this proportion by dividing it by the employment rate for youth with disabilities, measured through the ACS. A relative employment ratio of 1.0 for a VR agency indicates that youth who received services from that agency had employment outcomes equivalent to those of all youth with disabilities in the state. A ratio above or below 1.0 indicates that the employment outcomes of VR youth were, respectively, above or below those observed statewide for youth with disabilities. This relative employment ratio has the limitation of not accounting for variation among the states in the characteristics of youth served by VR agencies, such as severity of disability and age at application. The ratio attempts only to place the observed VR employment outcomes roughly in the context of the state-wide employment rate for youth with disabilities.

Across the United States, transition-age youth served by VR agencies had employment rates at closure that were, on average, 86 percent of the employment rates observed for all youth with disabilities in their respective states (Table III.4). Again, as with the other ratios, agencies had sizeable variation in the value of the relative employment ratio (Figure III.4). Ten agencies had 
values at or above 1.0, and five of those agencies (in Tennessee, Kentucky, Alabama, Maryland, and Mississippi) had values at or above 1.16. Four of these states are in the South, where employment rates for the general population of youth with disabilities tended to be at or below the national average. Thus, the normalization process typically increased the value of the relative employment ratio for these states. It is impossible, however, to determine whether these high ratios are due to selection issues or characteristics of the youth. That is, those who received services in Tennessee might have had more human capital or have been more persistent in seeking vocational services, leading to a higher likelihood of employment; these characteristics, rather than the specific services and programs provided by the agency, might result in the higher ratio. Among agencies at the low end of the range of values for the relative employment ratio, Oklahoma had the lowest value (45 percent). Six other VR agencies had ratios between 60 and 70 percent.

Figure III.4. Relative Employment Ratio (VR Youth with Employment Outcomes to State-Level Employed Youth with Disabilities), by State

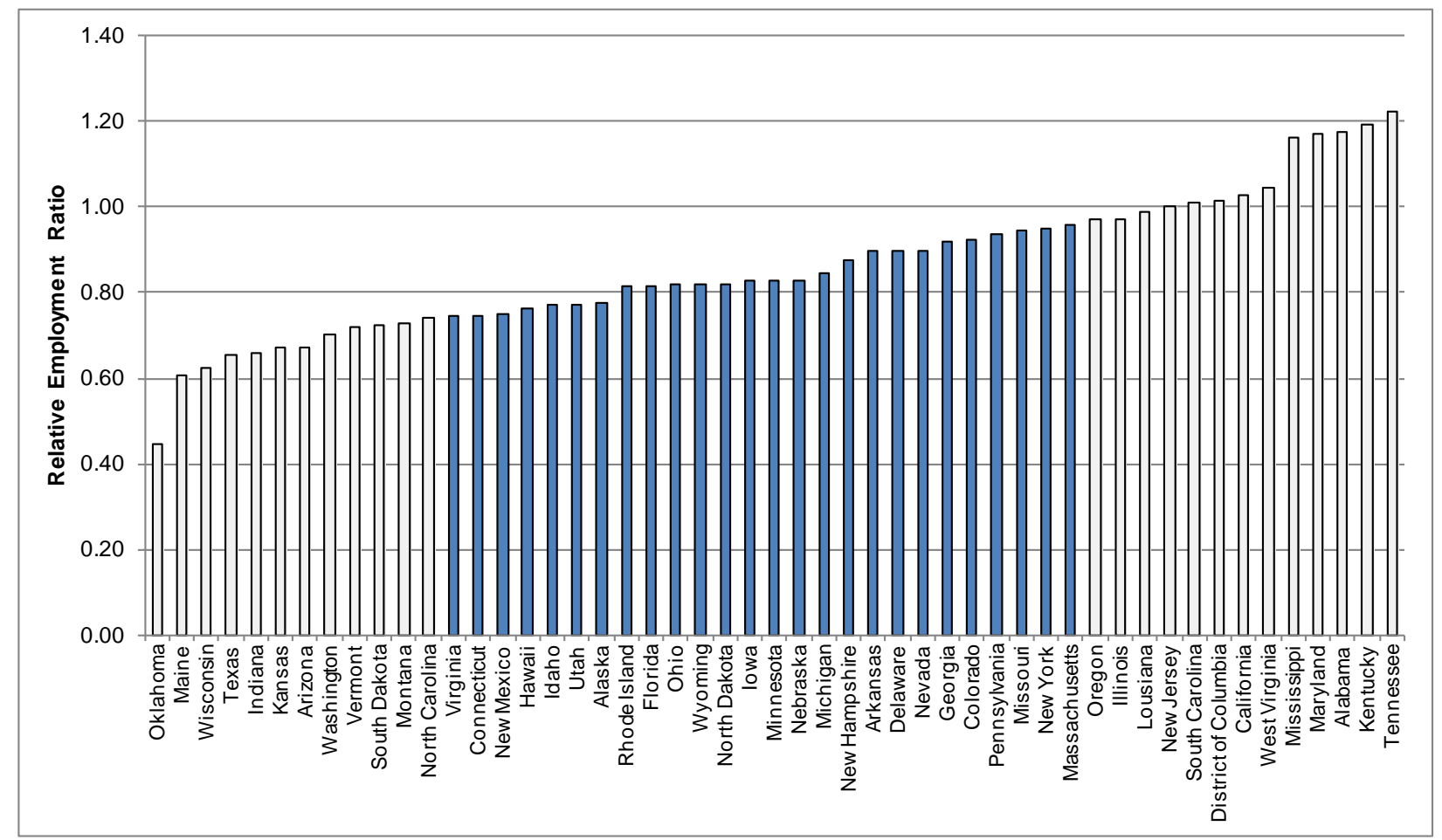

Sources: $\quad$ RSA-911 closure records, fiscal years 2004 through 2011; ACS 2004-2006.

Note: $\quad$ Data show the 2004, 2005, and 2006 average ratio of the proportion of VR youth served who closed with employment outcomes (numerator) and the proportion of youth aged 16 to 24 with a disability who were employed, as identified in the ACS (denominator). State VR agencies are ordered from lowest to highest. Bars that are not shaded indicate the agencies in the top and bottom quartiles of the distribution.

Proportion of all youth with disabilities who closed from VR with employment. Across the United States, 2.3 percent of transition-age youth who applied for and received VR services eventually were employed when they closed from services. The final two columns in Table III.4 show this aggregate measure for each agency (the product of the first three ratios) along with the associated quartile ranking ( 1 indicating the highest quartile and 4 the lowest); Figure III.5 shows the agencies from lowest to highest statistic. The U.S. map in Figure III.6 provides a graphical display of the quartile ranking of states; states in the first quartile are shaded dark gray and states with agencies in 
the fourth quartile are shaded white. Alabama had the highest value for this statistic (0.065). Among its transition-age youth population with disabilities, nearly 7 percent sought and received VR services and exited with an employment outcome. Part of the reason for the high value for the Alabama VR agency is the large proportion of youth applicants that it accepted for services. The agencies with the next highest value of this statistic (Delaware, West Virginia, North Dakota, Idaho, and Vermont) ranged from 0.045 to 0.055 . In contrast, the agencies in Louisiana, Connecticut, and Washington had the lowest values $(0.009,0.010$, and 0.010 , respectively). No more than 1 percent of youth in those states applied for and received services and exited with a positive employment outcome. For Louisiana, the values for the three component ratios were in the fourth quartile of the distributions of observed values. Alaska, Texas, and Tennessee also had notably low values of this statistic (each below 0.015).

Figure III.5. Proportion of Youth With Disabilities Who Closed from VR with Employment, by State

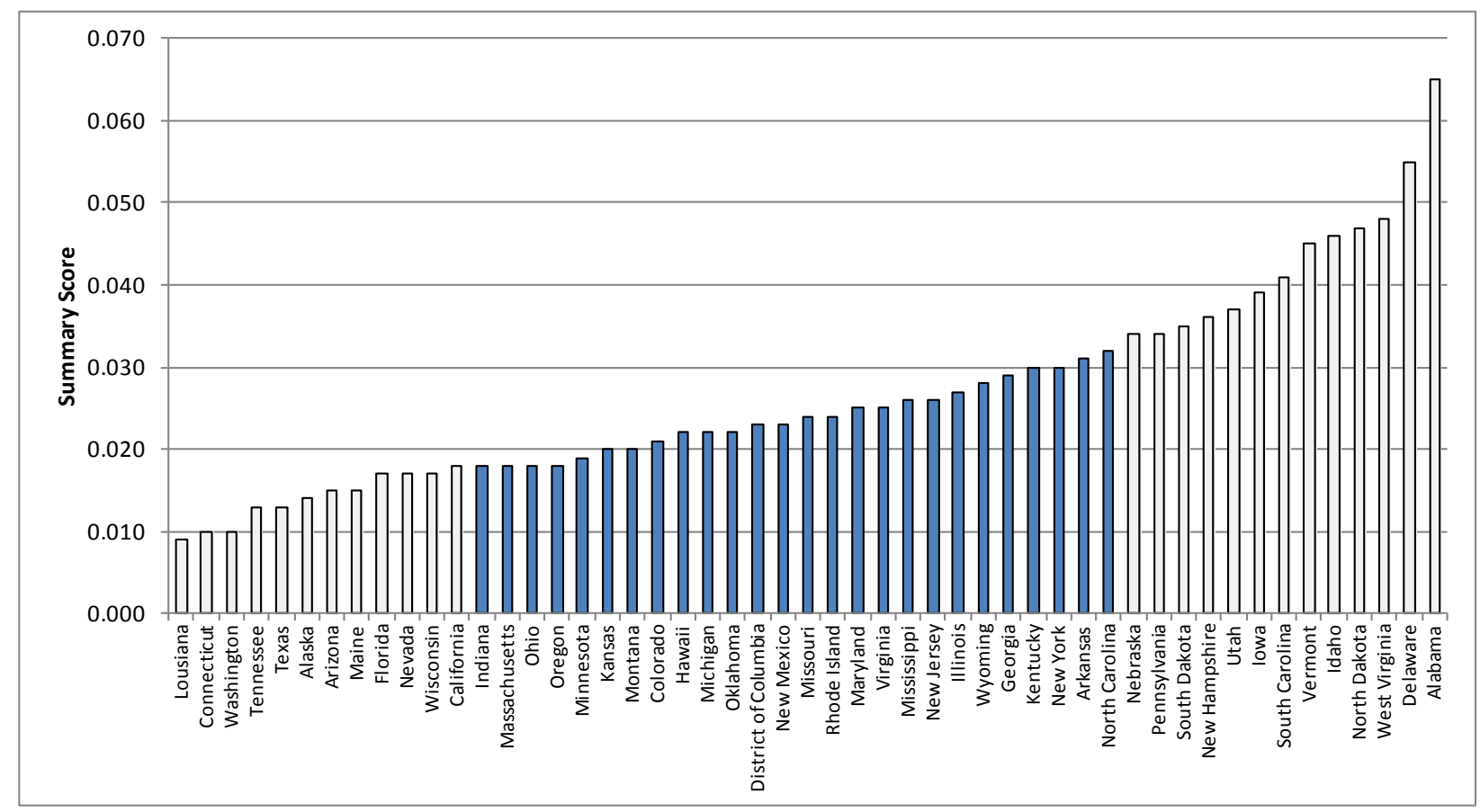

Sources: $\quad$ RSA-911 closure records, fiscal years 2004 through 2011; ACS 2004-2006.

Note: $\quad$ Data show the 2004, 2005, and 2006 proportion of transition-age youth with disabilities who received VR services and closed with employment outcomes (the product of the applicant, service, and employment ratios presented in Table III.4). VR agencies are ordered from lowest to highest. Bars that are not shaded indicate the agencies in the top and bottom quartiles of the distribution. 


\section{Figure III.6. Quartiles of the Proportion of Transition-Age Youth Who Received VR Services and Closed with Employment Outcomes, by State}

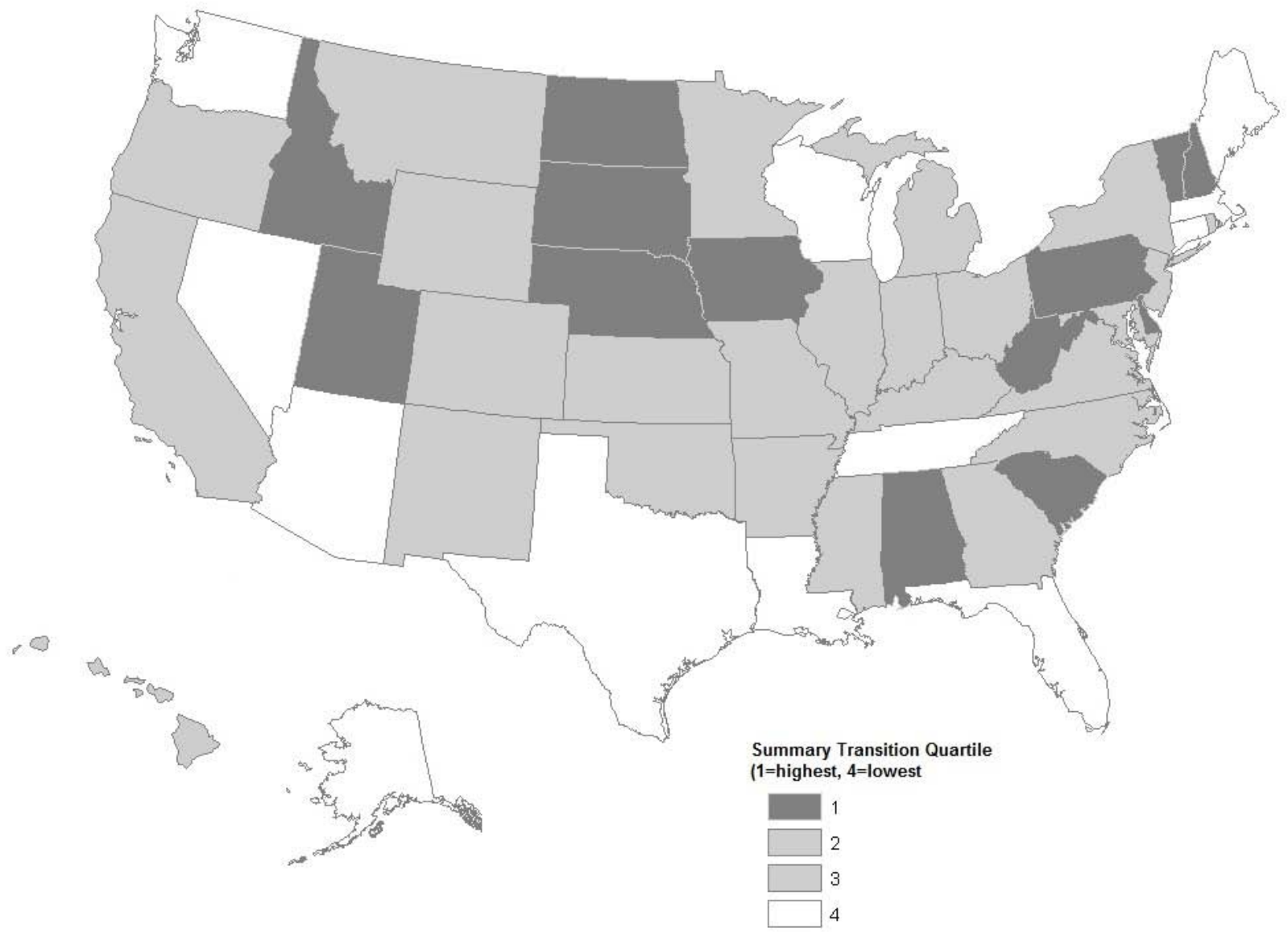

Sources: $\quad$ RSA-911 closure records, fiscal years 2004 through 2011; ACS 2004-2006.

Note: $\quad$ Data show the 2004, 2005, and 2006 proportions of transition-age youth with disabilities who received VR services and closed with an employment outcome (the product of the three transition-age youth ratios presented in Table III.4). States are shaded by quartile, with the lowest proportions shaded as dark gray and the highest proportions shaded as white.

A more qualitative perspective considers the ratios along with the relative employment ratio. Few agencies had consistently high or low values for all three of the component ratios and the relative employment ratio, with the Alabama VR agency, with consistently high values, being a notable exception. Instead, most agencies had higher values for one or two of the statistics, and lower values for the remaining statistics. The pattern of values can also be illustrative. Consider, for example, the Tennessee VR agency: although a small percentage of youth with disabilities who applied for services received them (likely a function of the agency's being in OOS), those youth who did receive services had relatively positive employment outcomes, at least compared with other youth with disabilities in the state who did not receive VR services. In contrast, the Vermont VR agency was in the highest quartile of values for the application and service ratios, but its value for the relative employment ratio was in the lowest quartile. The latter result was in part a function of the relatively high employment rate for non-VR youth with disabilities in the state.

Correlations across the five ratios are useful to explore the relationships among them (Table III.5). Three key themes emerge. First, the applicant, service, and employment ratios were largely 
independent of each other; the applicant ratio and employment ratios were moderately positively correlated $(\mathrm{r}=0.348, p<0.05)$. Second, although the applicant, service, and employment ratios each were strongly and positively correlated with the proportion of a state's youth with disabilities who closed from VR with employment, as expected, the correlation was strongest for the applicant ratio, indicating that it is the largest source of variation for the product of the three ratios. Third, the relative employment ratio was positively correlated with the employment ratio; the more positive an agency's employment outcomes for youth, the more likely those outcomes were similar to those of the state's transition-age population with disabilities.

Table III.5. Correlations among State VR Agency Transition Ratios

\begin{tabular}{|c|c|c|c|c|c|}
\hline & $\begin{array}{l}\text { Applicant } \\
\text { Ratio }\end{array}$ & $\begin{array}{l}\text { Service } \\
\text { Ratio }\end{array}$ & $\begin{array}{c}\text { Employment } \\
\text { Ratio }\end{array}$ & $\begin{array}{c}\text { Relative } \\
\text { Employment } \\
\text { Ratio }\end{array}$ & $\begin{array}{c}\text { Proportion of Youth } \\
\text { who Closed from VR } \\
\text { with Employment }\end{array}$ \\
\hline Applicant ratio & -- & 0.156 & $0.348^{*}$ & 0.096 & $0.851^{\star *}$ \\
\hline Service ratio & & -- & 0.056 & 0.039 & $0.547^{* *}$ \\
\hline Employment ratio & & & -- & $0.471^{\star *}$ & $0.541^{\star *}$ \\
\hline Relative employment ratio & & & & -- & 0.241 \\
\hline $\begin{array}{l}\text { Proportion of youth who closed } \\
\text { from VR with employment }\end{array}$ & & & & & -- \\
\hline
\end{tabular}

Sources: RSA-911 closure records, fiscal years 2004 through 2011; other sources as defined in the methods section.

Note: $\quad \mathrm{N}=51$. Table shows Pearson correlation coefficients among state VR agency transition ratios. Ratios are defined as in the note to Table III.4.

${ }^{*} p<.05 ;{ }^{* \star} p<.01$.

\section{Agency and State Factors Influencing the Transition-Age Youth Ratios}

The correlation analysis of how agency- and state-level factors influence the transition-age youth ratios revealed that a number of the factors were related to the applicant ratio but few were related to the other ratios. Table III.6 presents the results from that analysis. ${ }^{2}$ All associations discussed in this section are based on correlations that were significant at the 5 percent level.

2 An alternative analysis calculated the correlations of these variables using a $\log$ transformation of the variables. The results were similar, with the following differences for significance at the $p<0.05$ level: the number of transitionage youth was positively associated with the employment ratio; the number of youth receiving IDEA services was negatively associated with the employment ratio and the proportion of youth who closed from VR with employment measure; and the service expenditures on postsecondary education was positively associated with the service ratio. Each of these associations was significant at the $p<0.10$ level in Table III.6. 
Table III.6. Correlations of Agency and State Factors with Agency Transition Ratios

\begin{tabular}{|c|c|c|c|c|c|}
\hline & $\begin{array}{l}\text { Applicant } \\
\text { Ratio }\end{array}$ & $\begin{array}{l}\text { Service } \\
\text { Ratio } \\
\end{array}$ & $\begin{array}{c}\text { Employment } \\
\text { Ratio }\end{array}$ & $\begin{array}{c}\text { Relative } \\
\text { Employment } \\
\text { Ratio } \\
\end{array}$ & $\begin{array}{l}\text { Proportion of } \\
\text { Youth Who } \\
\text { Closed from } \\
\text { VR with } \\
\text { Employment }\end{array}$ \\
\hline \multicolumn{6}{|c|}{ Volume } \\
\hline Number of transition-age youth & $-0.283^{*}$ & 0.071 & 0.231 & 0.109 & -0.267 \\
\hline $\begin{array}{l}\text { Percentage of state population } \\
\text { represented by transition-age } \\
\text { youth }\end{array}$ & 0.057 & 0.020 & 0.138 & -0.224 & 0.066 \\
\hline $\begin{array}{l}\text { Percentage of transition-age youth } \\
\text { with a disability }\end{array}$ & $0.276^{*}$ & 0.079 & 0.024 & 0.059 & $0.294^{*}$ \\
\hline $\begin{array}{l}\text { Per-capita youth aged } 16 \text { to } 21 \\
\text { receiving services through IDEA }\end{array}$ & 0.086 & -0.024 & -0.078 & -0.046 & 0.038 \\
\hline Number of VR applicants & -0.100 & 0.097 & -0.268 & 0.113 & -0.143 \\
\hline \multicolumn{6}{|c|}{ Agency Resources } \\
\hline $\begin{array}{l}\text { Mean cost of purchased services } \\
\text { per youth served }\end{array}$ & -0.221 & $-0.480^{\star \star}$ & -0.216 & -0.236 & $-0.377^{* *}$ \\
\hline $\begin{array}{l}\text { Percent of service expenditures } \\
\text { related to postsecondary } \\
\text { education }\end{array}$ & 0.209 & -0.247 & 0.139 & 0.057 & 0.089 \\
\hline $\begin{array}{l}\text { Ratio of applicants to VR } \\
\text { counselors }\end{array}$ & $0.281^{*}$ & -0.071 & 0.151 & 0.041 & 0.167 \\
\hline $\begin{array}{l}\text { VR grant allotment per working-age } \\
\text { person with a disability }\end{array}$ & $0.417^{\star *}$ & -0.033 & 0.232 & -0.190 & $0.351^{*}$ \\
\hline \multicolumn{6}{|c|}{ Focus on Transition-Age Youth } \\
\hline $\begin{array}{l}\text { Had goals and programs related to } \\
\text { youth in state plan }\end{array}$ & 0.192 & -0.054 & 0.226 & 0.054 & 0.161 \\
\hline $\begin{array}{l}\text { Had dedicated state transition } \\
\text { leadership }\end{array}$ & -0.179 & 0.195 & -0.015 & 0.145 & 0.037 \\
\hline $\begin{array}{l}\text { Had VR counselors with dedicated } \\
\text { transition caseload }\end{array}$ & 0.220 & 0.202 & -0.106 & 0.199 & 0.186 \\
\hline \multicolumn{6}{|c|}{ Client Characteristics } \\
\hline $\begin{array}{l}\text { Referrals from education sources } \\
\text { (percentage) }\end{array}$ & 0.113 & -0.010 & -0.005 & 0.132 & 0.051 \\
\hline $\begin{array}{l}\text { Transition youth VR applicants with } \\
\text { IEP (percentage) }\end{array}$ & 0.146 & -0.043 & -0.057 & -0.005 & 0.053 \\
\hline $\begin{array}{l}\text { Transition youth VR applicants } \\
\text { employed at application } \\
\text { (percentage) }\end{array}$ & 0.256 & -0.160 & 0.110 & -0.250 & 0.148 \\
\hline \multicolumn{6}{|c|}{ State Economic Environment } \\
\hline Annual state unemployment rate & $-0.359 * *$ & -0.089 & -0.122 & $0.288^{*}$ & $-0.334^{*}$ \\
\hline Youth labor force participation rate & $0.311^{*}$ & -0.158 & $0.308^{*}$ & NA & 0.236 \\
\hline
\end{tabular}

Sources: $\quad$ RSA-911 closure records, fiscal years 2004 through 2011; other sources as defined in the methods section.

Note: $\quad \mathrm{N}=51(\mathrm{~N}=50$ for goals and programs related to youth in state plan; $\mathrm{N}=49$ for state transition leadership and dedicated transition counselor measures). Table shows Pearson correlation coefficients between state factors and state VR agency transition ratios. Ratios are defined as in the note to Table III.4. NA = not applicable (the youth labor force participation rate is the denominator for the relative employment ratio).

${ }^{*} p<.05 ;{ }^{* *} p<.01$. 
- The following factors were significantly correlated with the applicant ratio: the number of transition-age youth, the percentage of a state's transition-age youth population with a disability, the ratio of VR applicants to counselors, VR grant allotments, the state unemployment rate, and youth labor force participation. Available resources, in terms of the VR grant allocation and the ratio of applicants to counselors, had a positive association with the proportion of youth who seek services. Factors related to volume had inconsistent relationships with the ratio. First, agencies in states with a higher proportion of youth with disabilities tended to have had a higher number of youth who applied for VR; however, states with more transition-age youth (that is, states with larger populations) tended to have fewer youth with disabilities who applied. Finally, the positive relationship for youth labor force participation-and conversely, the negative relationship for unemployment rates-may signify the effect of an overall positive employment climate for youth in seeking VR services, as well as the desire for youth with disabilities to keep up with their peers without disabilities.

- One state-level factor was significantly correlated with the service ratio. The mean cost of purchased services per individual served was negatively correlated with the proportion of youth applicants served, and the magnitude of the correlation was among the strongest observed for any factor. One possible explanation is that agencies with higher per-capita costs may encounter more resource constraints that limit their ability to serve all youth interested in services.

- The two employment-focused ratios-the employment ratio and the relative employment ratio-were associated only with factors reflecting the state economic environment. The labor force participation rate of youth was positively associated with the employment of youth receiving VR services - that is, employment outcomes for youth served by VR tracked the employment of other youth with disabilities in the state. Conversely, the relative employment ratio was positively correlated with the state unemployment rate. These findings indicate a complicated association between the outcomes of youth with disabilities who received VR services and the state economic environment.

- Factors related to the proportion of a state's youth who closed from VR with an employment outcome include those that were associated with other transition-age youth ratios, for similar reasons as listed above: the percentage of transition-age youth in the state with a disability, the mean cost of purchased services per individual served, the VR grant allotment, and the annual unemployment rate.

Table III.7 shows mean values of the youth ratios for each of the two categorical agency variables - percentage of counselors with a dedicated transition-age youth caseload and OOS status. The sample of 51 agencies is too small for statistical tests, but some patterns are suggestive of potential associations. First, agencies with a higher proportion of transition counselors tended to have higher service ratios, relative employment ratios, and proportions of youth who closed from VR with employment. Second, agencies in OOS with larger wait lists tended to serve a lower proportion of youth applicants, which by definition resulted in a lower proportion of a state's youth with disabilities who closed from VR with employment. 
Table III.7. Ratio Means for Transition Counselor Level and OOS

\begin{tabular}{|c|c|c|c|c|c|c|}
\hline & $\mathrm{N}$ & $\begin{array}{l}\text { Applicant } \\
\text { Ratio }\end{array}$ & $\begin{array}{l}\text { Service } \\
\text { Ratio }\end{array}$ & $\begin{array}{l}\text { Employment } \\
\text { Ratio }\end{array}$ & $\begin{array}{l}\text { Relative } \\
\text { Employment } \\
\text { Ratio }\end{array}$ & $\begin{array}{l}\text { Proportion of } \\
\text { Youth Who } \\
\text { Closed from } \\
\text { VR with } \\
\text { Employment }\end{array}$ \\
\hline \multicolumn{7}{|c|}{ Percentage of Counselors with Dedicated Transition Caseloads } \\
\hline $0 \%$ & 12 & 0.07 & 0.51 & 0.59 & 0.80 & 0.023 \\
\hline $1 \%-5 \%$ & 14 & 0.09 & 0.54 & 0.59 & 0.90 & 0.028 \\
\hline $6 \%-10 \%$ & 6 & 0.07 & 0.51 & 0.51 & 0.82 & 0.018 \\
\hline $11 \%-15 \%$ & 6 & 0.09 & 0.57 & 0.56 & 0.83 & 0.029 \\
\hline $16 \%-20 \%$ & 4 & 0.08 & 0.61 & 0.58 & 0.90 & 0.030 \\
\hline $21 \%$ or more & 7 & 0.10 & 0.60 & 0.57 & 0.91 & 0.038 \\
\hline \multicolumn{7}{|l|}{ OOS Status } \\
\hline No oos & 20 & 0.09 & 0.58 & 0.56 & 0.84 & 0.030 \\
\hline OOS, no wait list & 11 & 0.08 & 0.57 & 0.61 & 0.90 & 0.031 \\
\hline $\begin{array}{l}\text { OOS, } 1 \text { to } 9 \text { percent } \\
\text { on wait list }\end{array}$ & 8 & 0.07 & 0.58 & 0.54 & 0.84 & 0.022 \\
\hline $\begin{array}{l}\text { OOS, } 10 \text { to } 49 \text { percent } \\
\text { on wait list }\end{array}$ & 3 & 0.08 & 0.43 & 0.57 & 1.07 & 0.019 \\
\hline $\begin{array}{l}\text { OOS, } 50 \text { percent or more } \\
\text { on wait list }\end{array}$ & 9 & 0.09 & 0.46 & 0.57 & 0.80 & 0.024 \\
\hline
\end{tabular}

Sources: $\quad$ RSA-911 closure records, fiscal years 2004 through 2011; RSA-113; VR Transition Study.

Note: $\quad \mathrm{N}=49$ (percentage of counselors with dedicated transition caseloads) and 51 (OOS status). Table shows mean state VR agency transition-age ratios for each categorical value of transition counselor percentage and OOS status. Ratios are defined as in the note to Table III.4. 
This page has been left blank for double-sided copying. 


\section{DISCUSSION}

This paper provides a first look at outcomes for cohorts of VR youth applicants by merging RSA-911 closure data over multiple years and by supplementing statistics for those applicants with state-level statistics from the ACS and other sources. We acknowledge three limitations of the study. First, it relies on state-level data. As such, it fails to control for the characteristics of individual VR applicants (such as disability severity or type) that could influence the results. Second, we can observe employment outcomes only of youth who receive VR services and who are employed at the time they closed from services. We have no information on the employment characteristics of youth who exit from VR agencies before receiving services, or about their long-term employment outcomes. Third, the analysis relies on descriptive and correlational statistics; we cannot determine causality among the various factors included in the study and the transition ratios.

VR agencies had sizeable variation in all five of the transition ratios regarding youth with disabilities who sought VR services. The differences between the agencies with the highest and lowest values of the measures of these dimensions were quite substantial, particularly for service provision and employment outcomes. That 31 percent of youth who sought services in Tennessee received them, compared with 56 percent of all youth in the United States and 82 percent of youth in Alabama, points to wide variation in application rates and access to service for transition-age youth. The range of values among the VR agencies on the employment ratio suggests similar degrees of differences across states in the ability of youth receiving services to find employment, an outcome that could be influenced by youth characteristics and local economic factors as well as the specific services an agency provides.

Several agency- and state-level factors, such as the unemployment rate and the amount of resources available to the VR agency, were correlated with the proportion of a state's youth with disabilities that applied for services. We found fewer factors to be associated with the service delivery and employment ratios, possibly because other factors that we could not observe may have been involved. Several financial factors - the mean cost of purchased services per individual served and OOS status - may limit an agency's ability to serve a larger number of youth. Also informative are our findings that a number of considered factors were not associated with the transition-age youth ratios. For example, having state-level VR leadership for transition services or VR counselors with dedicated transition caseloads was not associated with the ratios. This lack of association, however, may reflect our crude measurement of these factors; a more nuanced assessment of these factors might reveal some significant associations with the transition-age youth ratios. Other factors not included in this study may also influence transition outcomes. For instance, the quality of other service systems in a state (such as the education system and mental health services) may be influential, particularly if the VR agency has strong formal agreements with the agencies in charge of those systems that promote collaboration at the local and state levels. (All VR agencies have formal agreements with their state departments of education.)

Transition-age youth represent a substantial proportion-almost one-third-of the population served by VR agencies. Their unique vocational and education needs are one reason why many agencies have developed a strong focus on this population, such as having dedicated counselors and vocational programs specific for youth. The optimal level of resources that an agency should provide, however, is unknown. We have no information about the ideal amount of services or the proportion of youth with disabilities that should be served by VR agencies. As noted, the numbers presented in this study represent a first look at how agencies work with the transition-age populations in their states. High or low values do not indicate higher or lower performance by an agency; they are simply a snapshot of specific measures regarding the interactions of a cohort of 
youth applicants with state VR agencies, and a number of factors outside of an agency's control could influence these statistics.

One option policymakers have, should they want to promote the services received by this population, is to develop specific standards and indicators for agencies regarding the transition-age population. RSA currently has standards and indicators for the general population served by agencies (for example, the percentage with an employment outcome, the ratio of average hourly earnings of individuals who close with competitive employment to the average hourly earnings of employed individuals in the state). In addition, measures specific to transition-age youth as a special population are included in annual data reports, and detailed data are also available through a series of online monitoring tables. As part of its current agency monitoring process, RSA is undertaking a systematic review of the practices of each VR agency in working with transition-age youth. While these activities reflect RSA's interest in transition-age youth, expanding this focus by setting standards for all agencies on how each should serve this population, perhaps including goals for improvement, could have some effect on increasing the number of youth who receive services and thereby potentially obtain better employment outcomes. Such identification of goals and public monitoring of efforts around youth could result in some agencies changing how they work with youth. The key question, though, is to what standards to hold agencies; although this analysis does not provide an answer, it does show the wide variation in the transition ratios that currently exists across agencies.

Should RSA develop standards and guidelines for the transition-age population served by agencies, this study points to several limitations and challenges in consideration of such an approach. First, measurements, particularly regarding employment, should account for state characteristics (for example, the employment and wages of other transition-age youth or youth with disabilities). The ACS data are a relatively recent innovation that enable policymakers to incorporate such statistics into the standards they set. Second, it might be important to at least acknowledge, if not categorize, the different types of youth that states serve, such as youth who are in school when they apply for services versus those who have left secondary education, youth receiving SSI benefits or who have more severe disabilities, and youth in postsecondary education programs. Statistics could be very different depending on the types of youth who seek services and when in the transition process they encounter the VR agency. Lastly, measures based on cohorts of applicants as this study used, rather than cohorts of closures, might better control for various agency and state factors that could influence the behavior of youth to apply for, receive, and follow through with services to achieve employment outcomes.

This study's results suggest two possible directions for future research. First, further study is needed on agency practices that can influence the transition ratios presented in this study. For example, one factor that could influence the applicant ratio is a strong presence of transition counselors in a state's high schools (which might reflect strong interagency or cooperative agreements between an agency and the state department of education, as well as with the agency and local school districts). The same factor, though, might not influence a state's employment ratio. Second, the current analysis could be extended by conducting individual-level analyses on how individual, agency, and state characteristics influence service receipt and employment outcomes for transition-age youth. Analyses that combine RSA-911 data with other sources, such as Social Security Administration longitudinal data on benefit receipt and earnings, could provide additional insight into how such factors influence the experiences of transition-age youth with disabilities with state VR agencies. 


\section{REFERENCES}

Benz, Michael R., Lauren Lindstrom, and Tim Latta. "Improving Collaboration between Schools and Vocational Rehabilitation: The Youth Transition Program Model." Journal of Vocational Rehabilitation, vol. 13, no. 1, 1999, pp. 55-63.

Berry, Hugh G., and Leslie J. Caplan. "Employment and Earnings Growth among Transition-Age Supplemental Security Income Program Participants." Journal of Disability Policy Studies, vol. 21, no. 3, 2010, pp. 152-159.

Brewer, David, Arun Karpur, Sukyeong Pi, William Erickson, Darlene Unger, and Valerie Malzer. "Evaluation of a Multi-site Transition to Adulthood Program for Youth with Disabilities." Journal of Rehabilitation, vol. 77, no. 3, 2011, pp. 3-13.

Burkhauser, Richard V., Andrew J. Houtenville, and Jennifer R. Tennant. "Capturing the Elusive Working-Age Population with Disabilities: Reconciling Conflicting Social Success Estimates from the Current Population Survey and American Community Survey." Journal of Disability Policy Studies, online ahead of print. Available at http://dps.sagepub.com/content/early/recent. Accessed June 8, 2012.

Carter, Erik W., Diane Austin, and Audrey A. Trainor. "Predictors of Postschool Employment Outcomes for Young Adults with Severe Disabilities." Journal of Disability Policy Studies, vol. 23, no. 1, 2012, pp. 50-63.

Dean, David, John Pepper, Robert Schmidt, and Steven Stern. "The Effects of Vocational Rehabilitation for People with Mental Illness." Working paper, 2011. Available at http://people.virginia.edu/ $\sim$ sns 5 r/resint/vocrehstf/vocrehmi.pdf.

Fraker, Thomas. "The Youth Transition Demonstration: Lifting Employment Barriers for Youth with Disabilities.” Issue Brief 13-01. Washington, DC: Center for Studying Disability Policy, February 2013.

Gonzalez, Rene, David A. Rosenthal, and Jeong Han Kim. "Predicting Vocational Rehabilitation Outcomes of Young Adults with Specific Learning Disabilities: Transitioning from School to Work." Journal of Vocational Rehabilitation, vol. 34, 2011, pp. 163-172.

Hart, Debra, Karen Zimbrich, and Claire Ghiloni. "Interagency Partnerships and Funding: Individual Supports for Youth with Significant Disabilities as They Move into Postsecondary Education and Employment Options." Journal of Vocational Rehabilitation, vol. 16, 2001, pp. 145154.

Horvath-Rose, Ann E., David C. Stapleton, and Bonnie O'Day. "Trends in Outcomes for Young People with Work Disabilities: Are We Making Progress?” Journal of Vocational Rehabilitation, vol. 21, no. 3, 2004, pp. 175-187.

Mann, David R., and Todd Honeycutt. "Disability Onset of Youth and Their Outcomes as Young Adults." Journal of Disability Policy Studies, forthcoming. 
Rangarajan, Anu, Thomas Fraker, Todd Honeycutt, Arif Mamun, John Martinez, Bonnie O’Day, and David Wittenburg. "The Social Security Administration's Youth Transition Demonstration Projects: Evaluation Design Report." Report submitted to the Social Security Administration, Office of Program Development and Research. Washington, DC: Mathematica Policy Research, January 2009.

Shandra, Carrie L., and Dennis P. Hogan. "School-to-Work Program Participation and the PostHigh School Employment of Young Adults with Disabilities." Journal of Vocational Rehabilitation, vol. 29, no. 2, 2008, pp. 117-130.

Silverstein, Robert. "A Description and Analysis of the Federal and Selected State Policy Frameworks Regarding Order of Selection Under Title I of the Rehabilitation Act." Boston, MA: Institute for Community Inclusion, Rehabilitation Research and Training Center on Vocational Rehabilitation, January 2010.

Social Security Administration. "SSI Annual Statistical Report, 2011." Table 35. Publication No. 1311827. Washington, DC: SSA, September 2012. Available at http://www.ssa.gov/policy/ docs/statcomps/ssi asr/2011/index.html.

The Study Group, Inc. "An Assessment of Transition Policies and Practices in State Vocational Rehabilitation Agencies.” Kill Devil Hills, NC: The Study Group, Inc., June 2007.

U.S. Census Bureau. "Design and Methodology: American Community Survey." Washington, DC: U.S. Government Printing Office, 2006.

U.S. Department of Education. "29th Annual Report to Congress on the Implementation of the Individuals with Disabilities Act, 2007, Volume 1.” Washington, DC: Author, 2010.

U.S. Department of Education, Office of Special Education and Rehabilitative Services, Rehabilitation Services Administration. Annual Report, Fiscal Year 2009, Report on Federal Activities Under the Rehabilitation Act. Washington, DC: Author, 2012.

U.S. Government Accountability Office. "Vocational Rehabilitation Funding Formula: Options for Improving Equity in State Grants and Considerations for Performance Incentives." GAO-09798. Washington, DC: Government Accountability Office, September 2009.

Wittenburg, David C., and Pamela J. Loprest. "Early Transition Experiences of Transition-Age Child SSI Recipients.” Journal of Disability Policy Studies, vol. 18, no. 3, 2007, pp. 176-187. 
APPENDIX A

\section{AGENCY- AND STATE-LEVEL DATA}

FOR TABLES III.1, III.2 AND III.3 
This page has been left blank for double-sided copying. 
State Differences in the Vocational Rehabilitation Experiences of Transition-Age Youth with Disabilities

DRC Working Paper 2013-02

40112.305

August 2013

Todd Honeycutt, Allison Thompkins, Maura Bardos, and Steven Stern

Mathematica Policy Research

P. O. Box 2393

Princeton, NJ 08543

http://www.disabilitypolicyresearch.org/DRC/

(609) 945-3397

Appendix Tables

This document contains agency- and state-level statistics for the information used in the analysis of the working paper, "State Differences in the Vocational Rehabilitation Experiences of Transition-Age Youth with Disabilities." The methods section of the working paper provides details on the sources and calculations.

\section{Table/Tab}

Appendix Table 1a

Appendix Table $1 \mathrm{~b}$

Appendix Table 2

Appendix Table 3a

Appendix Table 3b

Appendix Table 3c

\section{Description}

Contains agency-level data on youth demographic characteristics (as summarized in Table 1 of the working paper).

Contains agency-level data on youth education and referral source characteristics (as summarized in Table 1 of the working paper).

Contains agency- and state-level data for volume measures, agency resources, client characteristics, and economic environment (as summarized in Table 2 of the working paper).

Contains agency-level data on transition focus (as summarized in Table 3 of the working paper).

Contains agency-level data for transition staff characteristics (as summarized in Table 3 of the working paper).

Contains agency-level data for order of selection status (as summarized in Table 3 of the working paper). 


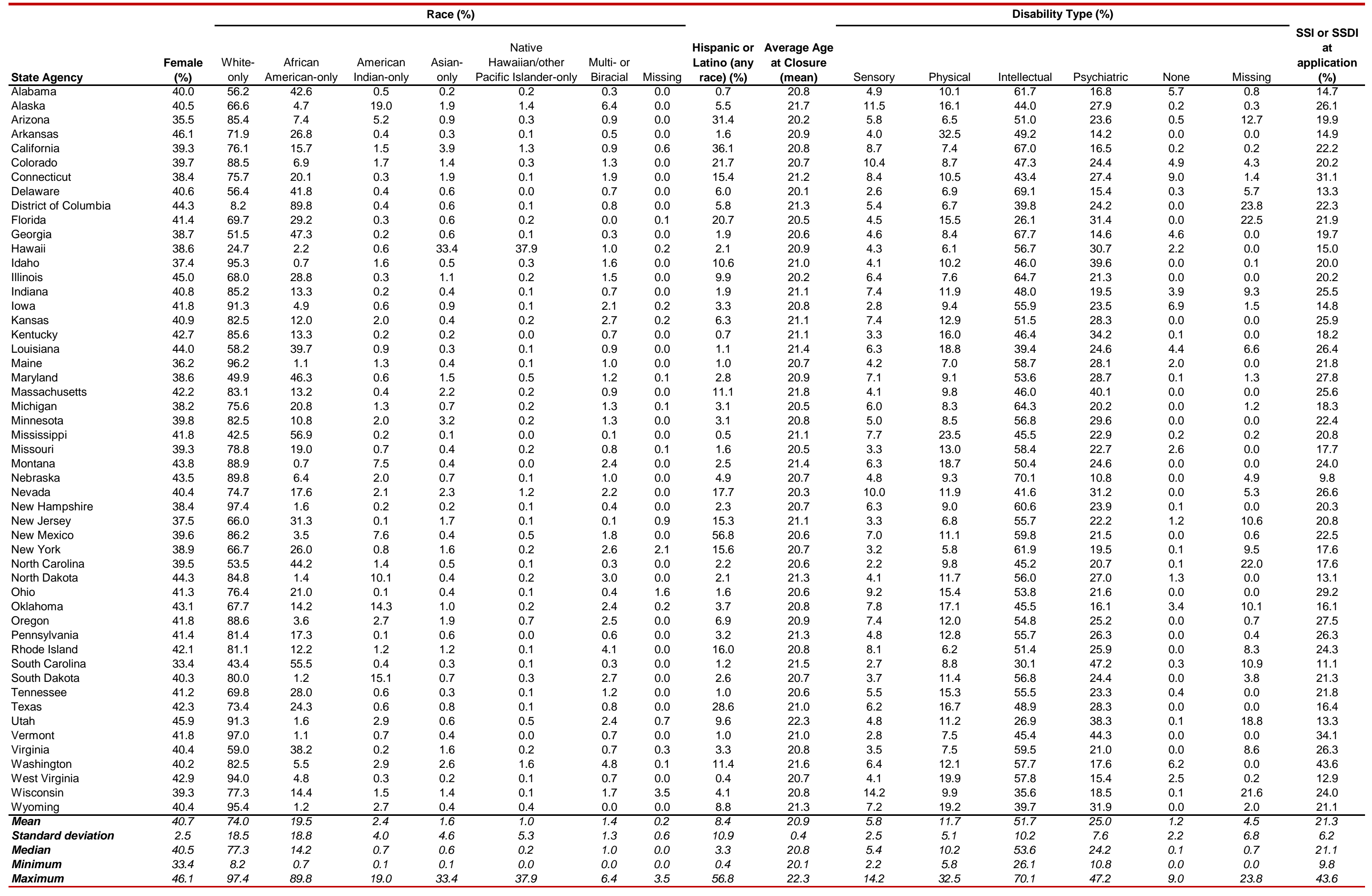

Source:

RSA-911 closure records, fiscal years 2004 through 2011 
Appendix Table 1b. Descriptive Statistics of the Individual Characteristics of VR Applicants Aged 16 to 24, 2004-2006

\begin{tabular}{|c|c|c|c|c|c|c|c|c|c|c|c|c|c|c|c|}
\hline \multirow[b]{2}{*}{ State Agency } & \multicolumn{4}{|c|}{ Educational Attainment at Application (\%) } & \multirow[b]{2}{*}{$\begin{array}{l}\text { Individualized } \\
\text { Eddcation } \\
\text { Program }(\%)\end{array}$} & \multicolumn{10}{|c|}{ Referral Source (\%) } \\
\hline & $\begin{array}{l}\text { Less than } \\
\text { high school }\end{array}$ & $\begin{array}{l}\text { High school } \\
\text { graduate }\end{array}$ & $\begin{array}{l}\text { Post- } \\
\text { secondary }\end{array}$ & Missing & & $\begin{array}{l}\text { Educational } \\
\text { institutition } \\
\text { (elementary) } \\
\text { secondary) }\end{array}$ & $\begin{array}{l}\text { Educational } \\
\text { institution } \\
\text { (post- } \\
\text { secondary) }\end{array}$ & $\begin{array}{c}\text { Medical } \\
\text { personnel }\end{array}$ & $\begin{array}{l}\text { Welfare } \\
\text { agency }\end{array}$ & $\begin{array}{l}\text { Community } \\
\text { renabilitation } \\
\text { programs }\end{array}$ & $\begin{array}{l}\text { Social Security } \\
\text { Administration }\end{array}$ & $\begin{array}{l}\text { One-Stop } \\
\text { employment } \\
\text { center }\end{array}$ & Self & Other & Missing \\
\hline Alabama & 78.4 & 14.4 & 7.2 & 0.0 & 65.6 & 57.8 & 2.3 & 0.5 & 1.5 & 1.7 & 0.5 & 2.7 & 14.1 & 18.9 & 0.0 \\
\hline Alaska & 47.0 & 41.5 & 11.5 & 0.0 & 65.0 & 26.8 & 6.0 & 5.1 & 3.1 & 10.1 & 1.1 & 3.9 & 20.8 & 23.2 & 0.0 \\
\hline Arizona & 71.9 & 21.4 & 6.8 & 0.0 & 44.4 & 36.1 & 8.8 & 1.1 & 2.1 & 4.8 & 0.4 & 0.6 & 16.7 & 29.5 & 0.0 \\
\hline Arkansas & 38.0 & 50.6 & 11.5 & 0.0 & 38.0 & 46.7 & 4.6 & 4.8 & 1.8 & 0.7 & 0.5 & 0.5 & 22.2 & 18.2 & 0.0 \\
\hline California & 66.3 & 24.4 & 8.5 & 0.8 & 52.5 & 52.9 & 8.4 & 3.4 & 0.9 & 12.3 & 0.7 & 1.4 & 9.0 & 11.1 & 0.1 \\
\hline Colorado & 50.1 & 43.2 & 6.0 & 0.7 & 23.4 & 59.3 & 1.3 & 8.9 & 1.4 & 0.2 & 0.4 & 0.4 & 12.0 & 16.0 & 0.0 \\
\hline Connecticut & 63.4 & 27.8 & 8.7 & 0.2 & 79.0 & 43.3 & 6.2 & 8.1 & 2.1 & 6.2 & 0.9 & 1.4 & 15.2 & 16.3 & 0.1 \\
\hline Delaware & 75.5 & 20.1 & 4.4 & 0.0 & 55.1 & 64.4 & 1.0 & 2.8 & 0.6 & 5.1 & 0.2 & 0.5 & 13.8 & 11.6 & 0.0 \\
\hline District of Columbia & 30.7 & 62.2 & 7.1 & 0.0 & 62.1 & 54.3 & 2.9 & 0.4 & 2.1 & 5.4 & 1.3 & 0.0 & 16.1 & 17.5 & 0.0 \\
\hline Florida & 70.1 & 20.5 & 5.4 & 4.0 & 54.0 & 48.6 & 3.5 & 5.1 & 0.3 & 1.7 & 0.4 & 0.8 & 25.1 & 14.5 & 0.0 \\
\hline Georgia & 78.3 & 15.6 & 6.1 & 0.0 & 66.2 & 60.3 & 5.4 & 2.5 & 1.9 & 3.3 & 0.6 & 1.0 & 16.0 & 8.9 & 0.0 \\
\hline Hawaii & 63.8 & 27.2 & 9.0 & 0.0 & 75.0 & 52.0 & 5.0 & 3.9 & 0.7 & 3.6 & 0.3 & 1.2 & 18.1 & 15.2 & 0.0 \\
\hline Idaho & 54.8 & 37.9 & 7.3 & 0.0 & 60.7 & 36.0 & 1.8 & 6.9 & 0.5 & 2.8 & 0.7 & 1.4 & 14.7 & 35.2 & 0.0 \\
\hline Illinois & 73.8 & 19.1 & 7.0 & 0.0 & 87.1 & 62.9 & 5.3 & 1.2 & 0.7 & 5.5 & 0.2 & 0.2 & 16.2 & 7.7 & 0.0 \\
\hline Indiana & 55.4 & 33.8 & 10.9 & 0.0 & 37.4 & 33.5 & 5.0 & 4.9 & 2.2 & 8.4 & 0.7 & 1.9 & 22.9 & 20.5 & 0.0 \\
\hline lowa & 68.6 & 22.1 & 9.3 & 0.0 & 73.8 & 57.6 & 8.7 & 2.9 & 4.3 & 3.9 & 0.3 & 1.1 & 5.7 & 15.2 & 0.3 \\
\hline $\begin{array}{l}\text { Kansas } \\
\text { Kentucky }\end{array}$ & 51.8 & 35.1 & 13.1 & 0.0 & 79.1 & & 1.6 & 2.3 & 6.5 & 7.4 & 1.5 & 1.1 & 15.4 & 23.8 & 0.0 \\
\hline $\begin{array}{l}\text { Kentucky } \\
\text { Lousizana }\end{array}$ & 59.3 & & 9.9 & 0.0 & 39.0 & 44.8 & 6.0 & 8.3 & 1.8 & 4.6 & 0.7 & 1.7 & 13.1 & 19.0 & 0.0 \\
\hline $\begin{array}{l}\text { Louisiana } \\
\text { Maine }\end{array}$ & 53.5 & 29.6 & 17.0 & 0.0 & 49.5 & 29.9 & 2.7 & 6.0 & 0.6 & 1.0 & 0.7 & 0.4 & 25.1 & 33.5 & 0.0 \\
\hline $\begin{array}{l}\text { Maine } \\
\text { Maryland }\end{array}$ & 80.8 & 16.2 & 3.0 & 0.0 & 82.5 & 58.7 & 4.1 & 3.9 & 2.0 & 7.2 & 0.4 & 1.3 & 7.5 & 14.4 & 0.5 \\
\hline $\begin{array}{l}\text { Maryland } \\
\text { Massachusetts }\end{array}$ & $\begin{array}{l}61.6 \\
557.7\end{array}$ & $\begin{array}{l}31.0 \\
35.8\end{array}$ & 7.4 & 0.0 & $\begin{array}{l}76.8 \\
457\end{array}$ & 44.7 & 4.6 & 4.3 & 1.5 & 9.2 & 1.1 & 1.6 & 16.9 & 16.1 & 0.0 \\
\hline $\begin{array}{l}\text { Massachusetts } \\
\text { Michigan }\end{array}$ & $\begin{array}{l}52.7 \\
68.8\end{array}$ & $\begin{array}{l}35.8 \\
26.5\end{array}$ & $\begin{array}{l}11.4 \\
4.7\end{array}$ & $\begin{array}{l}0.1 \\
0.0\end{array}$ & $\begin{array}{l}45.7 \\
78.8\end{array}$ & $\begin{array}{l}29.9 \\
64.3\end{array}$ & 5.5 & $\begin{array}{l}4.4 \\
67\end{array}$ & 1.5 & $\begin{array}{r}7.5 \\
25\end{array}$ & 0.4 & 1.5 & $\begin{array}{l}22.9 \\
83\end{array}$ & 26.4 & 0.0 \\
\hline Minnesota & $\begin{array}{l}00.0 \\
71.0\end{array}$ & $\begin{array}{l}26.5 \\
21.8\end{array}$ & $\begin{array}{l}4.1 \\
7.1\end{array}$ & $\begin{array}{l}0.0 \\
0.1\end{array}$ & $\begin{array}{l}8.8 \\
85.2\end{array}$ & $\begin{array}{l}64.3 \\
61.6\end{array}$ & $\begin{array}{l}3.1 \\
3.7\end{array}$ & $\begin{array}{l}6.1 \\
3.7\end{array}$ & $\begin{array}{l}0.6 \\
7.1\end{array}$ & $\begin{array}{l}2.5 \\
3.0\end{array}$ & $\begin{array}{l}0.7 \\
0.8\end{array}$ & $\begin{array}{l}1.6 \\
2.1\end{array}$ & $\begin{array}{l}8.3 \\
7.5\end{array}$ & 12.1 & 0.0 \\
\hline Mississippi & 62.3 & 26.7 & 11.0 & 0.0 & 45.9 & 33.9 & $\begin{array}{l}3.1 \\
0.7\end{array}$ & $\begin{array}{l}.11 \\
19.8\end{array}$ & $\begin{array}{l}.1 \\
0.4\end{array}$ & $\begin{array}{l}3.0 \\
1.5\end{array}$ & $\begin{array}{l}0.8 \\
0.6\end{array}$ & $\begin{array}{l}2.1 \\
0.6\end{array}$ & $\begin{array}{l}.5 \\
194\end{array}$ & $\begin{array}{l}10.5 \\
23.2\end{array}$ & $\begin{array}{l}0.0 \\
0.0\end{array}$ \\
\hline Missouri & 66.5 & 24.5 & 9.0 & 0.0 & 67.9 & 47.2 & 1.1 & 4.7 & $\begin{array}{l}.4 \\
1.3\end{array}$ & $\begin{array}{l}1.5 \\
0.7\end{array}$ & $\begin{array}{l}0.6 \\
0.5\end{array}$ & $\begin{array}{l}.6 \\
0.0\end{array}$ & $\begin{array}{l}19.4 \\
157\end{array}$ & $\begin{array}{l}23.2 \\
28.8\end{array}$ & $\begin{array}{l}0.0 \\
0.0\end{array}$ \\
\hline Montana & 55.1 & 32.8 & 12.0 & 0.0 & 58.8 & 23.5 & 6.5 & 7.9 & 4.3 & 6.0 & 1.3 & 1.8 & 14.9 & $\begin{array}{l}20.0 \\
33.7 \\
\end{array}$ & 0.0 \\
\hline Nebraska & 52.3 & 44.5 & 3.3 & 0.0 & 47.5 & 51.7 & 0.0 & 5.4 & 7.2 & 1.1 & 0.6 & 3.8 & 12.3 & 17.8 & 0.0 \\
\hline Nevada & 61.0 & 32.1 & 6.9 & 0.0 & 49.4 & 46.7 & 2.8 & 7.5 & 2.7 & 1.8 & 1.5 & 1.3 & 9.8 & 25.8 & 0.0 \\
\hline New Hampshire & 67.0 & 26.7 & 6.0 & 0.4 & 70.5 & 48.7 & 2.5 & 3.1 & 0.7 & 8.2 & 0.5 & 3.8 & 16.6 & 15.9 & 0.0 \\
\hline New Jersey & 59.4 & 33.7 & 6.9 & 0.0 & 64.0 & 45.0 & 9.4 & 4.0 & 1.6 & 7.2 & 0.6 & 2.1 & 20.4 & 9.4 & 0.2 \\
\hline New Mexico & 62.1 & 29.6 & 8.3 & 0.0 & 77.1 & 45.8 & 4.2 & 6.2 & 1.0 & 1.6 & 0.6 & 0.4 & 19.1 & 21.2 & 0.0 \\
\hline New York & 75.9 & 17.1 & 5.1 & 1.9 & 80.4 & 55.0 & 0.8 & 0.8 & 0.4 & 1.4 & 0.1 & 1.0 & 11.2 & 26.3 & 3.1 \\
\hline North Carolina & 72.0 & 20.4 & 7.6 & 0.0 & 36.9 & 47.5 & 1.8 & 10.8 & 1.1 & 1.1 & 0.6 & 2.1 & 19.0 & 15.9 & 0.0 \\
\hline North Dakota & 55.7 & 31.7 & 12.5 & 0.0 & 68.5 & 47.9 & 5.8 & 11.3 & 1.5 & 2.1 & 0.6 & 2.7 & 9.0 & 19.2 & 0.0 \\
\hline Ohio & 54.4 & 33.4 & 9.9 & 2.3 & 53.1 & 27.8 & 4.1 & 2.8 & 1.2 & 8.5 & 0.3 & 1.9 & 25.1 & 28.4 & 0.0 \\
\hline Oklahoma & 62.1 & 25.2 & 12.1 & 0.6 & 55.9 & 43.7 & 12.3 & 3.0 & 2.1 & 2.4 & 0.8 & 0.9 & 11.7 & 22.4 & 0.6 \\
\hline Oregon & 52.2 & 38.8 & 9.0 & 0.0 & 76.8 & 32.2 & 1.6 & 6.5 & 1.4 & 1.6 & 0.6 & 2.3 & 17.9 & 35.7 & 0.0 \\
\hline Pennsylvania & 62.1 & 25.7 & 12.3 & 0.0 & 67.9 & 41.3 & 3.8 & 4.3 & 0.9 & 9.2 & 0.5 & 0.8 & 25.8 & 13.5 & 0.0 \\
\hline Rhode Island & 73.5 & 19.1 & 7.4 & 0.0 & 49.4 & 50.5 & 5.0 & 2.2 & 6.1 & 7.3 & 1.0 & 1.0 & 18.3 & 8.5 & 0.0 \\
\hline South Carolina & 69.7 & 22.7 & 7.7 & 0.0 & 30.5 & 23.9 & 0.7 & 10.4 & 2.5 & 1.3 & 0.7 & 1.0 & 17.6 & 41.9 & 0.0 \\
\hline South Dakota & 62.7 & 26.7 & 10.4 & 0.3 & 82.4 & 39.9 & 5.4 & 5.2 & 1.7 & 12.1 & 0.4 & 4.7 & 13.4 & 17.2 & 0.0 \\
\hline $\begin{array}{l}\text { Tennessee } \\
\text { Toxas }\end{array}$ & 76.7 & 17.6 & 5.8 & 0.0 & 71.7 & 65.4 & 2.5 & 2.7 & 1.7 & 3.7 & 0.5 & 1.7 & 10.8 & 10.9 & 0.0 \\
\hline Texas & 55.6 & 34.4 & 9.9 & 0.1 & 51.4 & 47.9 & 7.6 & 4.7 & 1.0 & 3.3 & 0.6 & 1.0 & 17.3 & 16.3 & 0.0 \\
\hline $\begin{array}{l}\text { Utah } \\
\text { Vermont }\end{array}$ & 30.5 & 52.3 & 17.2 & 0.0 & 33.2 & 14.9 & 8.3 & 7.6 & 4.7 & 10.0 & 0.6 & 2.8 & 21.5 & 29.5 & 0.0 \\
\hline $\begin{array}{l}\text { Vermont } \\
\text { Virginia }\end{array}$ & 54.2 & 39.1 & 6.7 & 0.0 & 76.2 & 25.0 & 3.4 & 2.4 & 6.9 & 21.3 & 0.1 & 2.0 & 18.3 & 20.6 & 0.0 \\
\hline $\begin{array}{l}\text { Virginia } \\
\text { Washington }\end{array}$ & $\begin{array}{l}78.3 \\
655\end{array}$ & 14.8 & $\begin{array}{l}6.9 \\
84\end{array}$ & 0.0 & 80.3 & 57.4 & 3.1 & 7.2 & 2.0 & 0.6 & 0.4 & 0.9 & 14.2 & 14.2 & 0.0 \\
\hline $\begin{array}{l}\text { Washington } \\
\text { West Virginia }\end{array}$ & $\begin{array}{l}65.5 \\
72.6\end{array}$ & $\begin{array}{l}26.1 \\
16.5\end{array}$ & $\begin{array}{l}8.4 \\
10.9\end{array}$ & $\begin{array}{l}0.0 \\
0.0\end{array}$ & $\begin{array}{l}22.9 \\
59.8\end{array}$ & $\begin{array}{l}45.2 \\
56.3\end{array}$ & $\begin{array}{l}4.3 \\
8.1\end{array}$ & $\begin{array}{l}2.5 \\
29\end{array}$ & $\begin{array}{l}4.0 \\
19\end{array}$ & 3.0 & $\begin{array}{l}1.2 \\
0.4\end{array}$ & 1.5 & $\begin{array}{l}14.4 \\
17.3\end{array}$ & $\begin{array}{l}23.9 \\
104\end{array}$ & $\begin{array}{l}0.0 \\
0.0\end{array}$ \\
\hline $\begin{array}{l}\text { West Virinia } \\
\text { Wisconsin }\end{array}$ & $\begin{array}{l}72.6 \\
55.2\end{array}$ & $\begin{array}{l}16.5 \\
35.6\end{array}$ & $\begin{array}{l}10.9 \\
6.8\end{array}$ & $\begin{array}{l}0.0 \\
2.5\end{array}$ & $\begin{array}{l}59.8 \\
49.5\end{array}$ & $\begin{array}{l}56.3 \\
42.7\end{array}$ & $\begin{array}{l}8.1 \\
5.3\end{array}$ & $\begin{array}{l}2.9 \\
6.1\end{array}$ & $\begin{array}{l}1.9 \\
2.4\end{array}$ & $\begin{array}{l}1.7 \\
4.5\end{array}$ & $\begin{array}{l}0.4 \\
1.5\end{array}$ & $\begin{array}{l}0.9 \\
1.4\end{array}$ & $\begin{array}{l}17.3 \\
11.4\end{array}$ & $\begin{array}{l}10.4 \\
21.9\end{array}$ & $\begin{array}{l}2.0 \\
2.7\end{array}$ \\
\hline Wyoming & 42.3 & 45.8 & 12.0 & 0.0 & 25.3 & 27.2 & 5.7 & 7.5 & 3.0 & 10.4 & 0.6 & 3.2 & 16.5 & 26.0 & 0.0 \\
\hline Mean & 61.6 & 29.4 & 8.7 & 0.3 & 59.4 & 45.1 & 4.4 & 5.1 & 2.2 & 4.9 & 0.7 & 1.5 & 16.0 & 19.9 & 0.1 \\
\hline Standard deviation & 11.7 & 10.4 & 3.0 & 0.8 & 17.5 & 12.4 & 2.6 & 3.4 & 1.8 & 4.1 & 0.3 & 1.0 & 4.9 & 8.0 & 0.6 \\
\hline Median & 62.1 & 27.2 & 8.3 & 0.0 & 60.7 & 46.7 & 4.2 & 4.7 & 1.7 & 3.7 & 0.6 & 1.4 & 16.1 & 18.2 & 0.0 \\
\hline Minimum & 30.5 & 14.4 & 3.0 & 0.0 & 22.9 & 14.9 & 0.0 & 0.4 & 0.3 & 0.2 & 0.1 & 0.0 & 5.7 & 7.7 & 0.0 \\
\hline Maximum & 80.8 & 62.2 & 17.2 & 4.0 & 87.1 & 65.4 & 12.3 & 19.8 & 7.2 & 21.3 & 1.5 & 4.7 & 25.8 & 41.9 & 3.1 \\
\hline
\end{tabular}


Appendix Table 2. Characteristics of States and State VR Agencies, 2004-2006

\begin{tabular}{|c|c|c|c|c|c|c|c|c|c|c|c|c|c|c|}
\hline \multirow[b]{2}{*}{ State Agency } & \multicolumn{5}{|c|}{ Volume Measures } & \multicolumn{4}{|c|}{ Agency Resources } & \multicolumn{3}{|c|}{ Client Characteristics } & \multicolumn{2}{|c|}{ State Economic Environment } \\
\hline & $\begin{array}{l}\text { Number of } \\
\text { transition-age } \\
\text { youth }\end{array}$ & $\begin{array}{l}\text { Percentage of } \\
\text { state popplation } \\
\text { represented by } \\
\text { transition-age } \\
\text { youth }\end{array}$ & $\begin{array}{l}\text { Percentage of } \\
\text { transition-age } \\
\text { youth with a } \\
\text { disability }\end{array}$ & $\begin{array}{l}\text { Per-capita youth } \\
\text { aged } 16 \text { to } 21 \\
\text { receiving } \\
\text { services through } \\
\text { IDEA }\end{array}$ & $\begin{array}{c}\text { Number of VR } \\
\text { applicants }\end{array}$ & $\begin{array}{l}\text { Mean cost of } \\
\text { purchased } \\
\text { services per } \\
\text { youth served }\end{array}$ & $\begin{array}{l}\text { Percentage of service } \\
\text { expenditures related to } \\
\text { post-secondary education }\end{array}$ & $\begin{array}{c}\text { Ratio of } \\
\text { applicants } \\
\text { to VR } \\
\text { counselors }\end{array}$ & $\begin{array}{l}\text { VR grant allotment } \\
\text { per working-age } \\
\text { person with a } \\
\text { disability }\end{array}$ & $\begin{array}{l}\text { Referrals from } \\
\text { education } \\
\text { sources (\%) }\end{array}$ & $\begin{array}{l}\text { Transition youth } \\
\text { VR applicants } \\
\text { with IEP (\%) }\end{array}$ & $\begin{array}{l}\text { Transition youth VR } \\
\text { applicants employed at } \\
\text { application (\%) }\end{array}$ & $\begin{array}{l}\text { Annual state } \\
\text { unemployment } \\
\text { rate }\end{array}$ & $\begin{array}{l}\text { Youth labor force } \\
\text { participation rate }\end{array}$ \\
\hline Alabama & 551,778 & 12.1 & 8.7 & 16.3 & 14,845 & $\$ 2,268$ & 18.8 & 84.3 & $\$ 114$ & 60.1 & 65.6 & 7.4 & 4.1 & 75.7 \\
\hline Alaska & 95,223 & 14.3 & 7.7 & 15.9 & 1,520 & $\$ 4,372$ & 15.7 & 104.7 & $\$ 153$ & 32.9 & 65.0 & 15.2 & 6.9 & 83.5 \\
\hline Arizona & 725,879 & 12.2 & 5.5 & 14.7 & 6,947 & $\$ 3,844$ & 11.4 & 73.2 & $\$ 128$ & 44.9 & 44.4 & 11.8 & 4.7 & 75.7 \\
\hline Arkansas & 336,811 & 12.1 & 8.6 & 18.2 & 6,535 & $\$ 2,879$ & 50.9 & 211.6 & $\$ 130$ & 51.3 & 38.0 & 13.4 & 5.4 & 79.5 \\
\hline California & $\begin{array}{l}4,539,486 \\
56018\end{array}$ & 12.6 & 5.3 & 14.0 & 40,652 & $\$ 3,022$ & 12.9 & 146.4 & $\$ 104$ & 61.2 & 52.5 & 4.5 & 5.5 & 69.3 \\
\hline $\begin{array}{l}\text { Colorado } \\
\text { Connecticut }\end{array}$ & $\begin{array}{l}567,048 \\
37789\end{array}$ & 12.1 & 6.2 & 12.8 & $\begin{array}{r}6,791 \\
3201\end{array}$ & $\begin{array}{l}\$ 1,696 \\
\$ 3053\end{array}$ & 6.4 & 124.9 & $\$ 109$ & 60.6 & $\begin{array}{l}23.4 \\
700\end{array}$ & 18.0 & 5.0 & 81.2 \\
\hline $\begin{array}{l}\text { Connecticut } \\
\text { Delaware }\end{array}$ & $\begin{array}{r}377,489 \\
97,370\end{array}$ & $\begin{array}{l}10.8 \\
11.6\end{array}$ & $\begin{array}{l}5.5 \\
7.3\end{array}$ & $\begin{array}{l}18.9 \\
17.8\end{array}$ & $\begin{array}{l}3,391 \\
2,226\end{array}$ & $\begin{array}{l}\$ 2,953 \\
\$ 2,946\end{array}$ & $\begin{array}{c}8.4 \\
14.5\end{array}$ & $\begin{array}{l}\begin{array}{l}130.7 \\
275.1\end{array}\end{array}$ & $\begin{array}{l}\$ 83 \\
\$ 141\end{array}$ & $\begin{array}{l}49.6 \\
65.1\end{array}$ & $\begin{array}{l}79.0 \\
55.1\end{array}$ & $\begin{array}{l}16.3 \\
15.1\end{array}$ & $\begin{array}{l}4.8 \\
3.8\end{array}$ & 77.9 \\
\hline District of Columbia & 57,205 & 9.8 & $\begin{array}{l}7.3 \\
7.0\end{array}$ & 24.6 & $\begin{array}{l}2,226 \\
1,971\end{array}$ & $\begin{array}{l}\$<, 940 \\
\$ 5,645\end{array}$ & $\begin{array}{l}14.5 \\
43.7\end{array}$ & $\begin{array}{l}2754.1 \\
154.8\end{array}$ & $\$ \$ \$ 240$ & $\begin{array}{l}65.1 \\
57.1\end{array}$ & $\begin{array}{l}55.1 \\
62.1\end{array}$ & $\begin{array}{l}15.1 \\
6.6\end{array}$ & $\begin{array}{l}3.8 \\
6.6\end{array}$ & $\begin{array}{l}82.6 \\
74.9\end{array}$ \\
\hline Florida & & 11.2 & 6.0 & 19.1 & 31,407 & $\$ 3,704$ & 47 & 2435 & $\$ \$ 119$ & 521 & 540 & 57 & 3.9 & 737 \\
\hline Georgia & $\begin{array}{l}1,120,806 \\
1,20\end{array}$ & 12.2 & 6.1 & 14.9 & 12.325 & $\$ 2,459$ & 12.6 & 129.0 & $\$ \$ 127$ & 65.7 & 66.2 & 12.1 & 4.9 & 73.8 \\
\hline Hawaii & 148,665 & 11.7 & 4.6 & 15.4 & $\begin{array}{l}2,379 \\
2,39\end{array}$ & $\$ 2,197$ & 20.0 & 157.4 & $\$ 138$ & 57.3 & 75.0 & 7.7 & 2.8 & 75.6 \\
\hline Idaho & 191,181 & 13.4 & 7.5 & 12.5 & $\begin{array}{l}2,1,573 \\
5\end{array}$ & $\$ 2,469$ & 18.2 & 193.5 & $\$ 165$ & 37.7 & 60.7 & 216 & 3.8 & 86.3 \\
\hline Illinois & $1,540,782$ & 12.1 & 5.1 & 19.5 & 18,150 & $\$ 3,014$ & 11.7 & 88.3 & $\$ 133$ & 68.5 & 87.1 & 10.1 & 5.6 & 76.6 \\
\hline Indiana & 749,051 & 11.9 & 7.1 & 20.8 & 14,761 & $\$ 5,605$ & 12.5 & 96.8 & $\$ 139$ & 38.5 & 37.4 & 16.9 & 5.3 & 80.0 \\
\hline lowa & $\begin{array}{l}366,366 \\
355770\end{array}$ & 12.3 & 6.1 & 20.5 & 7,767 & $\$ 2,542$ & 42.6 & 292.3 & $\$ 162$ & 66.4 & 73.8 & 31.1 & 4.2 & 87.4 \\
\hline $\begin{array}{l}\text { Kanssas } \\
\text { Kentucky }\end{array}$ & $\begin{array}{l}355,778 \\
488563\end{array}$ & 12.9 & 6.9 & 16.1 & $\begin{array}{r}6,259 \\
1^{12609}\end{array}$ & $\$ \$ \$, 276$ & 8.4 & $\begin{array}{l}101.0 \\
2303\end{array}$ & $\$ 154$ & 42.2 & 79.1 & 20.5 & 5.0 & 86.9 \\
\hline $\begin{array}{l}\text { Kentuctck } \\
\text { Louisiana }\end{array}$ & $\begin{array}{l}488,563 \\
589,501\end{array}$ & $\begin{array}{l}11.7 \\
13.3\end{array}$ & $\begin{array}{l}9.1 \\
7.9\end{array}$ & $\begin{array}{l}15.7 \\
13.7\end{array}$ & $\begin{array}{r}\begin{array}{r}33,696 \\
7,257\end{array} \\
7\end{array}$ & $\begin{array}{l}\$ 2,561 \\
\$ 4,808\end{array}$ & $\begin{array}{l}32.7 \\
21.5\end{array}$ & $\begin{array}{l}239.3 \\
134.4\end{array}$ & $\begin{array}{l}\$ 114 \\
\$ 154\end{array}$ & $\begin{array}{l}50.8 \\
32.9\end{array}$ & $\begin{array}{l}39.0 \\
495\end{array}$ & $\begin{array}{l}16.2 \\
232\end{array}$ & 5.9 & 77.4 \\
\hline Maine & $\begin{array}{l}589,501 \\
145,733\end{array}$ & $\begin{array}{l}13.3 \\
11.1\end{array}$ & $\begin{array}{l}7.9 \\
9.1\end{array}$ & $\begin{array}{l}13.1 \\
23.2\end{array}$ & $\begin{array}{l}, 2,25 \\
3,078\end{array}$ & $\begin{array}{l}\$ 4,080 \\
\$ 4,031\end{array}$ & $\begin{array}{l}21.5 \\
16.8\end{array}$ & $\begin{array}{l}134.4 \\
149.3\end{array}$ & $\begin{array}{l}\$ 154 \\
\$ 116\end{array}$ & $\begin{array}{l}32.9 \\
62.9\end{array}$ & $\begin{array}{l}49.5 \\
82.5\end{array}$ & $\begin{array}{l}23.2 \\
8.7\end{array}$ & $\begin{array}{l}4.1 \\
4.7\end{array}$ & $\begin{array}{l}72.6 \\
87.1\end{array}$ \\
\hline Maryland & 663096 & 11.9 & 5.8 & 156 & 9944 & $\$ 2695$ & 14.9 & 1420 & & 493 & 768 & 110 & 41 & 列 \\
\hline Massachusetts & 708,866 & $\begin{array}{l}11.0 \\
11.0\end{array}$ & $\begin{array}{l}6.0 \\
6.6\end{array}$ & 22.7 & 11,661 & $\$$ & $\begin{array}{l}19.9 \\
19.9\end{array}$ & 103.4 & $\$ 90$ & 35.5 & $\begin{array}{l}45.7 \\
45\end{array}$ & $\begin{array}{l}17.2 \\
17.2\end{array}$ & 5.0 & 797 \\
\hline $\begin{array}{l}\text { Michigan } \\
\text {. }\end{array}$ & $\begin{array}{l}1,229,007 \\
\text {. }\end{array}$ & 12.2 & 7.6 & 18.4 & 19,216 & $\$ 2,607$ & 19.7 & 170.3 & $\$ 115$ & 67.4 & 78.8 & $\begin{array}{l}11.2 \\
13.8\end{array}$ & 6.9 & 78.4 \\
\hline Minnesota & $\begin{array}{r}1,23,265 \\
623,\end{array}$ & 12.1 & 6.0 & 17.8 & 8,064 & $\$ 2,305$ & 17.2 & 105.3 & $\$ 133$ & 65.2 & 85.2 & 5.0 & 4.2 & 86.4 \\
\hline Mississippi & 377,496 & 13.0 & 8.0 & 15.5 & 9,468 & $\$ 2,236$ & 3.5 & 137.2 & $\$ 144$ & 34.4 & 45.9 & 9.0 & 6.6 & 71.2 \\
\hline Missouri & 709,965 & 12.2 & 7.6 & 18.3 & 15,771 & $\$ 5,286$ & 16.8 & 217.5 & $\$ 125$ & 48.3 & 67.9 & 14.0 & 5.3 & 82.8 \\
\hline & 115,796 & 12.4 & 7.7 & 15.5 & 3,317 & $\$ 5,355$ & 42.6 & 209.1 & $\$ 161$ & 30.0 & 58.8 & 21.4 & 3.7 & 83.1 \\
\hline $\begin{array}{l}\text { Nebraska } \\
\text { Nevada }\end{array}$ & $\begin{array}{l}228,220 \\
271269\end{array}$ & $\begin{array}{ll}13.0 \\
112\end{array}$ & 6.7 & 17.2 & $\begin{array}{l}4,272 \\
3256\end{array}$ & $\$ 1,570$ & 31.8 & 167.5 & $\$ 167$ & 51.7 & 47.5 & 3.5 & 3.6 & 86.6 \\
\hline $\begin{array}{l}\text { Nevada } \\
\text { New Hampshire }\end{array}$ & $\begin{array}{l}271,269 \\
149472\end{array}$ & 11.2 & $\begin{array}{l}4.5 \\
72\end{array}$ & 15.5 & $\begin{array}{l}3,056 \\
3,27\end{array}$ & $\begin{array}{l}\$ 2,899 \\
\$ 2617\end{array}$ & $\begin{array}{l}8.6 \\
159\end{array}$ & 139.6 & $\begin{array}{l}\$ 99 \\
\$ 114\end{array}$ & $\begin{array}{l}49.7 \\
51.7\end{array}$ & $\begin{array}{l}49.4 \\
705\end{array}$ & 11.4 & $\begin{array}{l}4.4 \\
3.7\end{array}$ & 74.9 \\
\hline New Jersey & $\begin{array}{l}149,4 / 2 \\
962,706\end{array}$ & $\begin{array}{l}11.4 \\
11.1\end{array}$ & $\begin{array}{l}7.2 \\
5.5\end{array}$ & $\begin{array}{l}21.9 \\
24.7\end{array}$ & $\begin{array}{l}3,1,127 \\
13508\end{array}$ & $\begin{array}{l}\$ 2,611 \\
\$ 3,173\end{array}$ & $\begin{array}{l}15.9 \\
19.4\end{array}$ & $\begin{array}{l}108.0 \\
221.3\end{array}$ & $\begin{array}{l}\$ 114 \\
\$ 104\end{array}$ & $\begin{array}{l}51.1 \\
54.4\end{array}$ & $\begin{array}{l}0.5 \\
64.0\end{array}$ & $\begin{array}{l}20.0 \\
12.9\end{array}$ & $\begin{array}{l}3.1 \\
4.7\end{array}$ & $\begin{array}{l}85.6 \\
73.7\end{array}$ \\
\hline New Mexico & 255221 & 13.2 & 69 & 187 & 5437 & $\$ 2604$ & 227 & 1247 & $\$ \$ 149$ & 501 & 771 & 157 & 51 & 757 \\
\hline New York & $2,227,374$ & 11.5 & 6.1 & $\begin{array}{l}19.3 \\
19.3\end{array}$ & 38.671 & $\$ 44,240$ & 8.0 & 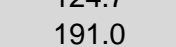 & $\$ 105$ & 55.7 & 80.4 & 63 & 52 & 685 \\
\hline North Carolina & 981,445 & 11.3 & 6.7 & 17.5 & 29,192 & $\$ 2,611$ & 7.8 & 168.9 & $\$ 126$ & 49.4 & 36.9 & 12.0 & 5.2 & 76.7 \\
\hline North Dakota & 85,489 & 13.5 & 7.2 & 15.1 & 2,445 & $\$$ & 26.7 & 132.5 & $\$ 277$ & 53.7 & 68.5 & 22.2 & 3.4 & 87.8 \\
\hline Ohio & $1,357,927$ & 11.8 & 7.2 & 20.0 & 26,476 & $\$ 5,183$ & 28.1 & 159.1 & $\$ 133$ & 31.9 & 53.1 & 15.4 & 5.8 & 80.8 \\
\hline Oklahoma & 441,976 & 12.5 & 8.1 & 20.9 & 8,839 & $\$ 3,333$ & 34.3 & 61.6 & $\$ 126$ & 56.1 & 55.9 & 19.6 & 4.6 & 79.9 \\
\hline Oregon & & 11.7 & 7.7 & 16.2 & & & 7.9 & 155.2 & $\$ 113$ & 33.8 & 76.8 & 10.8 & 6.4 & 79.1 \\
\hline $\begin{array}{l}\text { Pennsylvania } \\
\text { Phode clatand }\end{array}$ & $\begin{array}{r}1,411,710 \\
12156\end{array}$ & 11.4 & 6.9 & 20.8 & $\begin{array}{l}26,255 \\
201\end{array}$ & $\$ \$ \$, 414$ & 26.4 & $\begin{array}{l}84.4 \\
156.8\end{array}$ & $\$ 122$ & 45.1 & 67.9 & 12.3 & 5.1 & 78.6 \\
\hline $\begin{array}{l}\text { Rhode Island } \\
\text { South Carolina }\end{array}$ & $\begin{array}{l}124,656 \\
50,132\end{array}$ & $\begin{array}{l}11.6 \\
12.0\end{array}$ & $\begin{array}{l}7.2 \\
7.8\end{array}$ & $\begin{array}{l}24.4 \\
19.3\end{array}$ & $\begin{array}{r}2,049 \\
18,250\end{array}$ & $\$ 3,191$ & $\begin{array}{ll}10.7 \\
3.3\end{array}$ & $\begin{array}{l}156.8 \\
143.5\end{array}$ & $\$ \$ 118$ & $\begin{array}{l}55.4 \\
24.5\end{array}$ & $\begin{array}{l}49.4 \\
305\end{array}$ & $\begin{array}{l}12.1 \\
102\end{array}$ & 5.1 & $\begin{array}{l}81.3 \\
75 .\end{array}$ \\
\hline $\begin{array}{l}\text { Soutn Caroinna } \\
\text { South Dakota }\end{array}$ & $\begin{array}{l}509,132 \\
100,838\end{array}$ & $\begin{array}{l}12.0 \\
13.0\end{array}$ & $\begin{array}{l}7.8 \\
6.3\end{array}$ & $\begin{array}{l}19.3 \\
13.0\end{array}$ & $\begin{array}{r}\begin{array}{r}18,250 \\
2509\end{array} \\
2.04\end{array}$ & $\begin{array}{l}\$ 1,297 \\
\$ 3,613\end{array}$ & $\begin{array}{l}3.3 \\
11.3\end{array}$ & $\begin{array}{l}143.5 \\
147.8\end{array}$ & $\begin{array}{l}\$ 143 \\
\$ 174\end{array}$ & $\begin{array}{l}24.5 \\
45.4\end{array}$ & $\begin{array}{l}30.5 \\
82.4\end{array}$ & $\begin{array}{l}10.2 \\
21.1\end{array}$ & $\begin{array}{l}6.7 \\
3.5\end{array}$ & $\begin{array}{l}75.5 \\
87.5\end{array}$ \\
\hline Tennessee & 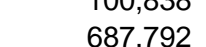 & 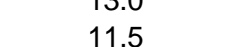 & $\begin{array}{l}6.3 \\
7.8\end{array}$ & $\begin{array}{l}13.0 \\
16.6\end{array}$ & 年, & 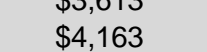 & $\begin{array}{l}11.3 \\
39.0\end{array}$ & $\begin{array}{l}14.8 \\
121.2\end{array}$ & $\$ \$ \$ 106$ & $\begin{array}{l}45.4 \\
67.9\end{array}$ & 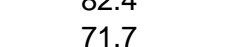 & 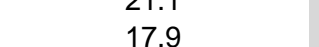 & 年. & 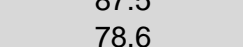 \\
\hline Texas & $2,957,380$ & 12.9 & 6.4 & 17.0 & 43,123 & $\$ 3,236$ & 10.6 & $\begin{array}{l}199.0 \\
199.0\end{array}$ & $\$ 129$ & 55.6 & 51.4 & 18.4 & 5.4 & 72.9 \\
\hline Utah & 382,556 & 15.4 & 5.5 & 12.6 & 7,677 & $\$ 3,600$ & 44.5 & 209.2 & $\$ 191$ & 23.4 & 33.2 & 21.6 & 4.1 & 87.7 \\
\hline Vermont & 7,73913 & 11.9 & 10.8 & 19.7 & 3,379 & $\$$ & 5.4 & 142.8 & $\$ 202$ & 28.3 & 76.2 & 20.7 & 3.6 & 89.0 \\
\hline Virginia & 884,581 & 11.7 & 6.3 & 19.2 & 10,403 & $\$ 2,001$ & 5.7 & 270.6 & $\$ 118$ & 60.5 & 80.3 & 14.6 & 3.5 & 80.5 \\
\hline Washington & 776,085 & 12.3 & 7.8 & 14.0 & 9,122 & $\$ 4,565$ & 18.6 & 69.5 & $\$ 97$ & 49.4 & 22.9 & 8.1 & 5.6 & 78.7 \\
\hline West Virginia & 203,114 & 11.2 & 8.5 & 21.7 & 5,116 & $\$ 2,239$ & 18.1 & 107.9 & $\$ 125$ & 64.6 & 59.8 & 14.9 & 5.0 & 74.4 \\
\hline $\begin{array}{l}\text { Wisconsin } \\
\text { Wyoming }\end{array}$ & 685,961 & 12.4 & 7.0 & 18.4 & 14,347 & $\$ 3,780$ & 15.0 & 199.3 & $\$ 148$ & 48.1 & 49.5 & 13.3 & 4.8 & 85.0 \\
\hline$\frac{\text { Wyoming }}{\text { Mean }}$ & $\begin{array}{r}66,960 \\
7000129\end{array}$ & $\frac{13.1}{121}$ & 6.8 & $\frac{16.3}{178}$ & $\frac{1,681}{11429}$ & $\$ 4,715$ & $\frac{18.0}{18.8}$ & $\frac{151.1}{153.9}$ & $\$ 250$ & $\frac{32.7}{495}$ & $\frac{25.3}{594}$ & 24.9 & 3.6 & $\frac{90.9}{70.9}$ \\
\hline $\begin{array}{l}\text { Mean } \\
\text { Standard deviation }\end{array}$ & $\begin{array}{l}700,308 \\
805,308\end{array}$ & $\begin{array}{l}12.1 \\
0.9\end{array}$ & $\begin{array}{l}1.0 \\
1.2\end{array}$ & $\begin{array}{l}1.8 \\
3.2\end{array}$ & $\begin{array}{l}1,4,499 \\
10,405\end{array}$ & $\begin{array}{l}\$, 1,148 \\
\$ 1,145\end{array}$ & $\begin{array}{l}18.8 \\
11.9\end{array}$ & $\begin{array}{l}153.9 \\
54.4\end{array}$ & $\begin{array}{l}\$ 138 \\
\$ 39\end{array}$ & $\begin{array}{l}49.5 \\
12.3\end{array}$ & $\begin{array}{l}59.4 \\
17.5\end{array}$ & $\begin{array}{l}14.4 \\
5.9\end{array}$ & $\begin{array}{l}4.8 \\
1.0\end{array}$ & $\begin{array}{l}7.8 \\
5.5\end{array}$ \\
\hline Median & 488,563 & 12.1 & 7.0 & 17.8 & $\begin{array}{l}\quad, 0,064 \\
8,064\end{array}$ & $\$ 3,022$ & 16.8 & 146.4 & $\$ 128$ & 50.8 & 60.7 & 14.0 & 4.9 & 79.5 \\
\hline Minimum & 57,205 & 9.8 & 4.5 & 12.5 & 1,520 & $\$ 1,297$ & 3.3 & 61.6 & $\$ 83$ & 23.4 & 22.9 & 3.5 & 2.8 & 68.5 \\
\hline Maximum & 4.539 .486 & 15.4 & 10.8 & 24.7 & 43.123 & $\$ 5,645$ & 50.9 & 292.3 & $\$ 277$ & 68.5 & 87.1 & 31.1 & 6.9 & 90.9 \\
\hline
\end{tabular}

Source:

RSA-911 closure records, fiscal years 2004 through 2011; ACS 2004-2006; other sources as defined in the methods section
Table shows descriptive statisitics for each state agency of the three-year averages of agency- and state-level variables. 
Appendix Table 3a. Transition Focus of State VR Agencies, 2004-2006

\begin{tabular}{|c|c|c|c|}
\hline State Agency & $\begin{array}{l}\text { Had goals and programs related } \\
\text { to youth in state plan }\end{array}$ & $\begin{array}{l}\text { Had dedicated state transition } \\
\text { leadership }\end{array}$ & $\begin{array}{c}\text { Had VR counselors with dedicated } \\
\text { transition caseload }\end{array}$ \\
\hline Alabama & & $\mathrm{X}$ & $\mathrm{X}$ \\
\hline Alaska & & $x$ & \\
\hline Arizona & & $x$ & $\mathrm{X}$ \\
\hline Arkansas & & & $x$ \\
\hline California & & $x$ & $x$ \\
\hline Colorado & & $x$ & \\
\hline Connecticut & & $x$ & \\
\hline Delaware & $x$ & $x$ & $x$ \\
\hline District of Columbia & & $x$ & \\
\hline Florida & $x$ & $x$ & $\mathrm{x}$ \\
\hline Georgia & & $x$ & $x$ \\
\hline Hawaii & $x$ & $x$ & $x$ \\
\hline Idaho & $x$ & & $x$ \\
\hline Illinois & $x$ & $x$ & $x$ \\
\hline Indiana & & $x$ & \\
\hline lowa & $x$ & & $x$ \\
\hline Kansas & & $x$ & \\
\hline Kentucky & & $x$ & $x$ \\
\hline Louisiana & & $x$ & $x$ \\
\hline Maine & & & $x$ \\
\hline Maryland & $x$ & $x$ & $x$ \\
\hline Massachusetts & & NA & NA \\
\hline Michigan & & $x$ & $x$ \\
\hline Minnesota & & $x$ & $x$ \\
\hline Mississippi & NA & $x$ & $x$ \\
\hline Missouri & $x$ & $x$ & $x$ \\
\hline Montana & & $x$ & \\
\hline Nebraska & & $x$ & $x$ \\
\hline Nevada & & NA & NA \\
\hline New Hampshire & $x$ & $x$ & $x$ \\
\hline New Jersey & & $x$ & \\
\hline New Mexico & & $x$ & $x$ \\
\hline New York & & & $x$ \\
\hline North Carolina & & $x$ & $x$ \\
\hline North Dakota & & $x$ & \\
\hline Ohio & & $x$ & $x$ \\
\hline Oklahoma & & $x$ & $x$ \\
\hline Oregon & $x$ & $x$ & $x$ \\
\hline Pennsylvania & $x$ & $x$ & $x$ \\
\hline Rhode Island & & $x$ & $x$ \\
\hline South Carolina & & $x$ & $x$ \\
\hline South Dakota & $x$ & $x$ & \\
\hline Tennessee & & $x$ & $x$ \\
\hline Texas & & $x$ & $x$ \\
\hline Utah & & $x$ & $x$ \\
\hline Vermont & & $x$ & $x$ \\
\hline Virginia & & $x$ & $x$ \\
\hline Washington & $x$ & & \\
\hline West Virginia & & $x$ & $x$ \\
\hline Wisconsin & & $x$ & $x$ \\
\hline Wyoming & & $x$ & \\
\hline Total Number & 13 & 43 & 37 \\
\hline
\end{tabular}

Sources: $\quad$ Study Group National Survey, 2006; RSA State Plans, 2004

Note: $\quad$ Variables as defined in the method section.

NA = Data were not available. 
Appendix Table 3b. Transition Staff of State VR Agencies, 2004-2006

OOS Category

No staff with dedicated transition caseloads

$\begin{array}{ll}\text { Alaska } & \text { Montana } \\ \text { Colorado } & \text { New Jersey } \\ \text { Connecticut } & \text { North Dakota } \\ \text { District of Columbia } & \text { South Dakota } \\ \text { Indiana } & \text { Washington } \\ \text { Kansas } & \text { Wyoming }\end{array}$

$1 \%-5 \%$ of counselors with dedicated transition caseloads

$\begin{array}{ll}\text { Arkansas } & \text { New Mexico } \\ \text { Delaware } & \text { Ohio } \\ \text { Hawaii } & \text { Oregon } \\ \text { lowa } & \text { Rhode Island } \\ \text { Kentucky } & \text { Tennessee } \\ \text { Mississippi } & \text { Utah } \\ \text { New Hampshire } & \text { Wisconsin }\end{array}$

$6 \%-10 \%$ of counselors with dedicated transition caseloads

Arizona

Louisiana

California

Missouri

Florida

Oklahoma

$11 \%-15 \%$ of counselors with dedicated transition caseloads

Idaho

South Carolina

Minnesota

Texas

New York

Virginia

$16 \%-20 \%$ of counselors with dedicated transition caseloads

Illinois

Nebraska

Michigan

Pennsylvania

$21 \%$ or more counselors with dedicated transition caseloads

Alabama

North Carolina

Georgia

Vermont

Maine

West Virginia

Maryland

Sources: $\quad$ Study Group National Survey, 2006

Note: Information from Massachusetts and Nevada is missing. 
Appendix Table 3c. Order of Selection (OOS) Characteristics of State VR Agencies, 2004-2006

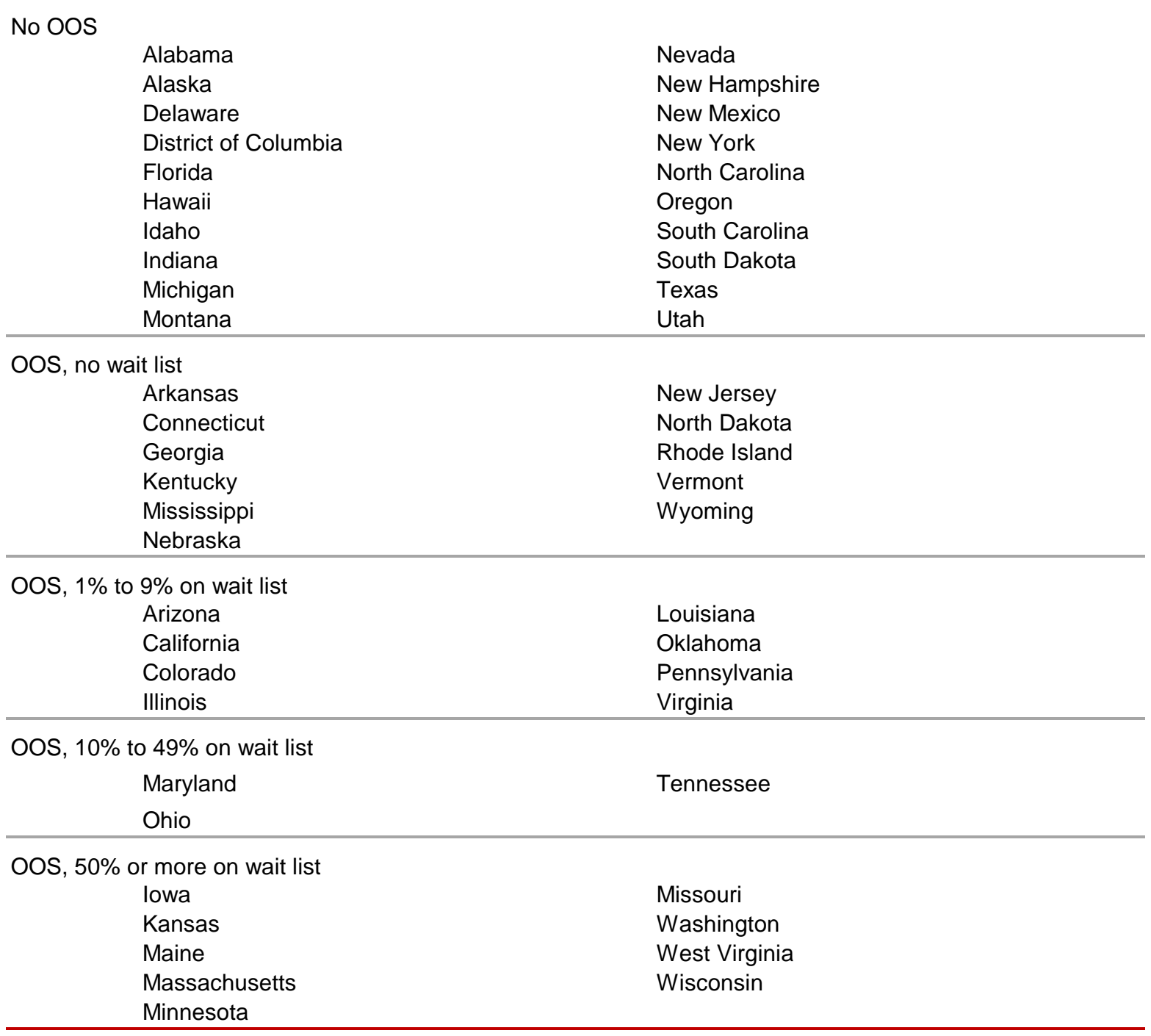

Sources: $\quad$ RSA-113, fiscal years 2004 through 2006. 
This page has been left blank for double-sided copying. 


\title{
MATHEMATICA Policy Research
}

\author{
www.mathematica-mpr.com
}

Improving public well-being by conducting high quality, objective research and surveys

Princeton, NJ - Ann Arbor, MI - Cambridge, MA - Chicago, IL - Oakland, CA - Washington, DC

Mathematica ${ }^{\circledR}$ is a registered trademark of Mathematica Policy Research 